\title{
Extreme Saharan dust event over the southern Iberian Peninsula in september 2007: active and passive remote sensing from surface and satellite
}

\author{
J. L. Guerrero-Rascado ${ }^{1,2}$, F. J. Olmo ${ }^{1,2}$, I. Avilés-Rodríguez ${ }^{1,2}$, F. Navas-Guzmán ${ }^{1,2}$, D. Pérez-Ramírez ${ }^{1,2}$, \\ H. Lyamani ${ }^{1,2}$, and L. Alados Arboledas ${ }^{1,2}$ \\ ${ }^{1}$ Departamento de Física Aplicada, Facultad de Ciencias, Universidad de Granada, Fuentenueva s/n, 18071, Granada, Spain \\ ${ }^{2}$ Centro Andaluz de Medio Ambiente (CEAMA), Junta de Andalucía-Universidad de Granada, Av. del Mediterráneo s/n, \\ 18071, Granada, Spain
}

Received: 14 April 2009 - Published in Atmos. Chem. Phys. Discuss.: 24 July 2009

Revised: 15 October 2009 - Accepted: 19 October 2009 - Published: 6 November 2009

\begin{abstract}
This study investigates aerosol optical properties during the extreme Saharan dust event detected from 3 to 7 September 2007 over Granada, southern Iberian Peninsula, with both active and passive remote sensing instrumentation from surface and satellite. The intensity of the event was visualized on the aerosol optical depth series obtained by the sun-photometer Cimel CE 318-4 operated at Granada in the framework of AERONET from August 2004 until December 2008 (level 2 data). A combination of large aerosol optical depth $(0.86-1.50)$ at $500 \mathrm{~nm}$, and reduced Angström exponent $(0.1-0.25)$ in the range $440-870 \mathrm{~nm}$, was detected on 6 September during daytime. This Saharan dust event also affected other Iberian Peninsula stations included in AERONET (El Arenosillo and Évora stations), and it was monitored by MODIS instrument on board Aqua satellite. Vertically resolved measurements were performed by a ground-based Raman Lidar and by CALIPSO satellite. During the most intense stage, on 6 September, maximum aerosol backscatter values were a factor of 8 higher than other maxima during this Saharan dust event. Values up to $1.5 \times 10^{-2} \mathrm{~km}^{-1} \mathrm{sr}^{-1}$ at 355 and $532 \mathrm{~nm}$ were detected in the layer with the greatest aerosol load between 3-4 km a.s.l., although aerosol particles were also detected up to $5.5 \mathrm{~km}$ a.s.l. In this stage of the event, dust particles at these altitudes showed a backscatter-related Angström exponent between -0.44 and 0.53 for the two spectral intervals considered. The results from different measurements (active/passive and
\end{abstract}

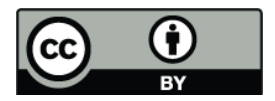

Correspondence to:

L. Alados Arboledas (alados@ugr.es) ground-based/satellite) reveal the importance of performing multi-instrumental measurements to properly characterize the contribution of different aerosol types from different sources during extreme events. The atmospheric stabilization effect of the aerosol particles has been characterized by computing the solar heating rates using SBDART code.

\section{Introduction}

Mineral dust particles originated over deserts like Sahara and Gobi play an important role on Earth's climate system. Dust particles interact with the solar and thermal radiation modulating Earth's radiative budget. According to the Fourth Report of the Intergovernmental Panel on Climate Change (Forster et al., 2007), the radiative forcing due to atmospheric aerosol has an error that is twofold its magnitude. In order to estimate the total uncertainty in the estimations of direct/indirect forcing, the uncertainties introduced by the different contributing factors must be known. In particular, dust particles introduce large uncertainties in the estimation of climate forcing due to atmospheric aerosol. It is accepted that dust particle radiation absorption can affect the thermal structure of the atmosphere (effects of warming/cooling by desert dust is strongly linked to its height; Gobbi et al., 2000) and, thus, the atmospheric circulation on synoptic scale (Pérez et al., 2006). In addition, dust particles modify microphysical properties of clouds, acting as condensation and ice nuclei, and can cause a decrease in the photolysis rates of ozone (Balis et al., 2002; Zerefos et al., 2002). Likewise, Saharan dust particle deposition affects biochemical cycles in

Published by Copernicus Publications on behalf of the European Geosciences Union. 
oceans (Kremling and Streau, 1993) and terrestrial ecosystems (Reichholf, 1986), as well as interfering with the monitoring of the anthropogenic component of $\mathrm{PM}_{10}$ levels over the Mediterranean countries (López et al., 2005).

On a global scale, the Sahara desert is the most important source of mineral dust (Papayannis et al., 2005; Liu et al., 2008). At present, the dust cycle is assessed using models constrained by the available measurements. In order to improve knowledge of mineral dust particles it is necessary to develop a data set of measurements with three-dimensional space and temporal resolution of dust aerosol. The Saharan dust aerosol properties and its spatial and temporal variability over the Iberian Peninsula during the dust events has already been studied using ground-based sun-photometer data in recent years (Olmo et al., 1999; Lyamani et al., 2004, 2005, 2006a, b, 2008; Elias et al., 2006; Díaz et al., 2007; Alados-Arboledas et al, 2008; Cachorro et al., 2008). However, comprehension of vertically resolved Saharan dust optical properties and their spatial and temporal evolution is still limited over our area. This is also true for the whole Mediterranean region, for which only a few publications exist, including non-systematic data on vertically resolved measurements of mineral dust particles optical properties (Hamonou et al., 1999; Gobbi et al., 2000; de Tomasi et al., 2003; Pappalardo et al., 2003; Balis et al., 2004; Papayannis et al., 2005; Müller et al., 2009), and a study with systematic measurements (Papayannis et al., 2008).

In this paper we present an analysis of the extreme Saharan dust event detected over the period from 3 to 7 September 2007 over Granada (Spain, 37.16 N, 3.61 ${ }^{\circ} \mathrm{W}$ ), southern Iberian Peninsula and monitored by the Atmospheric Physics Group of the University of Granada. Special emphasis is paid to the uniqueness of this event over our region, which was monitored with both active and passive remote sensing instrumentation. Section 2 gives a brief description of the experimental site and the instrumentation employed in this study. Sections 3-5 are focused both on the synoptic conditions which prevailed over southern Iberian Peninsula during the period from 3-7 September 2007, and on the analysis of the photometric and Lidar data. Section 6 presents the consequences of this extreme Saharan dust event on the atmospheric vertical structure.

\section{Experimental site and instrumentation}

Measurements of atmospheric aerosol have been performed in the urban area of Granada $\left(37.16^{\circ} \mathrm{N}, 3.61^{\circ} \mathrm{W}\right.$ and $680 \mathrm{~m}$ a.s.1.). Granada, located in south-eastern Spain is a non-industrialized, medium-sized city with a population of 300000,600000 if the whole metropolitan area is considered. The city is situated in a natural basin surrounded by mountains with altitudes over $1000 \mathrm{~m}$. The highest range is located at the East of the valley and corresponds to Sierra Nevada.
The near-continental conditions prevailing at this site are responsible for large seasonal temperature differences, providing cool winters and hot summers. The area also experiences periods of a low humidity regime especially at summer time. The study area is also at a short distance, about $200 \mathrm{~km}$ away from the African continent and approximately $50 \mathrm{~km}$ away from the western Mediterranean basin.

Due to its location in the Mediterranean basin, Granada is influenced by two major aerosol source regions: Europe as a major source of anthropogenic pollutants and North Africa as principal source of natural dust. Furthermore, the Mediterranean area is characterized by a complex meteorology which favors the aging of polluted air masses in the basin and induces high level of airborne particles. Thus, the Mediterranean basin can represent an additional source of atmospheric aerosol for the study area. In summer, the study area is isolated from travelling lows and associated frontal systems, and the intensification of the Azorean high during the warm season induces a very weak pressure gradient and a strong subsidence that reduces entrainment from the free troposphere. High temperatures and low humidity in summer induce numerous forest fires in the Iberian Peninsula, whose smoke represents an additional source of atmospheric aerosol to our study area.

Daytime, column-integrated characterization of the atmospheric aerosol has been done by means of a sun-photometer CE-318-4 included in the AERONET network (Holben at al., 1998). This sun-photometer makes direct sun measurements with a $1.2^{\circ}$ full field of view at $340,380,440,675,870,940$, and $1020 \mathrm{~nm}$. The full-width at half-maximum of the interference filters are $2 \mathrm{~nm}$ at $340 \mathrm{~nm}, 4 \mathrm{~nm}$ at 380 and $10 \mathrm{~nm}$ at all other wavelengths. Solar extinction measurements are used to obtain aerosol optical depth at each wavelength except at $940 \mathrm{~nm}$ which is used to retrieve total column water vapour. A complete description can be found in Holben et al. (1998).

Night-time measurements of columnar aerosol have been done by means of a star photometer, Excalibur, based on a Schmidt-Cassegrain telescope. A complete description is given by Pérez-Ramírez et al. (2008a, b).

The Raman Lidar model LR331D400 (Raymetrics S.A., Greece) is described in detail by Guerrero-Rascado et al. (2008). It is configured in a monostatic biaxial alignment pointing vertically to the zenith and based on a pulsed $\mathrm{Nd}$ :YAG laser. The fundamental emission is at $1064 \mathrm{~nm}$, however additional emissions at 532 and $355 \mathrm{~nm}$ are obtained by using second and third harmonic generators. The receiving system is a Cassegrainian telescope and a wavelength separation unit that consists of dichroic mirrors, interferential filters and a polarization cube. Detection is carried out in seven channels corresponding to elastic wavelengths at $1064,532 \mathrm{p}$ (parallel-polarized), $532 \mathrm{~s}$ (perpendicularpolarized) and $355 \mathrm{~nm}$, and 387 (nitrogen Raman-shifted signal from $355 \mathrm{~nm}$ ), $408 \mathrm{~nm}$ (water vapour Raman-shifted signal from $355 \mathrm{~nm}$ ) and $607 \mathrm{~nm}$ (nitrogen Raman shifted signal 
from $532 \mathrm{~nm}$ ). Due to the low intensity of Raman signals, they are only used for retrievals at night-time when the sky background is low and steady enough. Since November 2004, the Raman Lidar was operated at Granada station, and in April 2005, the instrument was incorporated to the EARLINET network (Bösenberg et al., 2001).

\section{General context of the extreme Saharan dust event}

In order to describe this extreme Saharan dust event over southern Iberian Peninsula, several tools have been employed. The HYSPLIT.4 model has been used (Draxler and Rolph, 2003) to calculate five-day backtrajectories of air masses coming to Granada at six different altitudes above ground level (a.g.l.) using the GDAS database (Global Data Assimilation System, ftp://www.arl.noaa.gov/pub/archives/ gdas1/), as Fig. 1 shows. For 3 September the air mass origin at low levels (500 and $1500 \mathrm{~m}$ a.g.l.) is the Mediterranean basin and Europe, and at higher levels the back-trajectories pass over the Iberian Peninsula and North Atlantic. For 4 September it is clear that a change took place in the synoptic conditions favouring passage of the air masses over North Africa (marginally). For 5-7 September the air masses at several levels indicated North African origin and thus mineral dust particles could be expected to advect to Granada from this source region. In this period the low level backtrajectories indicate European and Mediterranean origin so anthropogenic particles could be detected in our area. Finally, on 8 September the flow pattern changes, being residually of North African origin at high levels and of European and Mediterranean origin at low and medium levels.

In general, forecast models predicted this Saharan dust event. The Navy Aerosol Analysis and Prediction System (NAAPS) model (http://www.nrlmry.navy.mil/aerosol/) predicts the generation of a dust-loaded plume over North Africa and subsequent transport, affecting the South of Iberian Peninsula. According to the NAAPS simulations, the dust plume shifted north-westward and arrived at Granada on 5 September. The highest values of aerosol optical depth (up to 0.8 at $550 \mathrm{~nm}$ ) were forecasted for 6 September over southern Iberian Peninsula. On 7 September the dust plume kept shifting north-westward and, on 8 September finally only a residual concentration was predicted over the North Atlantic. In Fig. 2 the DREAM model (http://www.bsc.es/ projects/earthscience/DREAM) forecast is presented. Results are in agreement with those provided by NAAPS model, except that the DREAM model forecasts a longer event duration, concluding on 9 September (versus 8 September predicted by the NAAPS model). This dust event has been confirmed visually from satellite by the Aqua-MODIS images (http://modis.gsfc.nasa.gov). The Saharan dust event is captured by the image sequence (not shown here). The images clearly show the outflow of a dense aerosol layer from North
Africa on 4 September which is visually intense on 6 September as predicted by the forecasting models.

\section{Passive remote sensing southern Iberian Peninsula}

This unique Saharan dust event is characterized for its extreme intensity over the southern Iberian Peninsula. The intensity of the event is evident in the aerosol optical depth series obtained by Cimel CE 318-4 at Granada from August 2004 until December 2008 (AERONET level 2 data), and has been confirmed to be the most intense event for this period. The time series of the instantaneous values of aerosol optical depth at 500 and $550 \mathrm{~nm}$, derived from the Cimel CE 318-4 and Excalibur, respectively, are given in Fig. 3. The same figure shows the Angström Exponent values calculated in the ranges $440-870 \mathrm{~nm}$ and $440-880 \mathrm{~nm}$ derived from Cimel CE 318-4 and Excalibur measurements, respectively. The aerosol optical depth uncertainty derived by Cimel CE 318-4 sunphotometer is of the order of 0.01 at wavelengths larger than $440 \mathrm{~nm}$ and around 0.02 at wavelengths shorter than this value. According to the error propagation theory, the Angström exponent uncertainty can be estimated as 0.2 (Holben et al., 1998). Similarly, the aerosol optical depth uncertainty derived by Excalibur starphotometer is in the range 0.01 to 0.03 for the different wavelengths.

On the first days of the analyzed period (3-4 September) the column integrated aerosol optical properties values are associated with local aerosol contributions. Diurnal cycles observed in the Angström exponent for these days, with a minimum located around midday, are typical in our region during summer due to local processes. The mean Angström exponent presents a decreasing trend over the event with values lower than 1 and a minimum during the middle days. On 6 September, when the intense dust event influences the area, a sharp increase in aerosol optical depth is evident. Thus, a combination of large aerosol optical depth in the range $0.86-1.50$ at $500 \mathrm{~nm}$ and reduced Angström exponent in the range $0.1-0.25$, was detected on 6 September during daytime. These values correspond to a dust-loaded plume, caught by the MODIS Aqua, coming from North Africa and shifting northwestward. The strong anti-correlation between the aerosol optical depth and Angström exponent evidenced in Fig. 3, in combination with the reduced values of this last parameter, is a clear signature of coarse dust particles included in the atmospheric column (Lyamani et al., 2005, 2006a). After this intense stage, mean values are similar to those during previous days before the arrival of Saharan dust mineral particles.

Figure 4 presents volumetric size distributions retrieved throughout the selected period. While all distributions exhibit two modes, the relative weight for each mode depends on the dominant aerosol particles in the atmospheric column. In general, fine mode is associated with anthropogenic particles whereas the presence of a coarse 

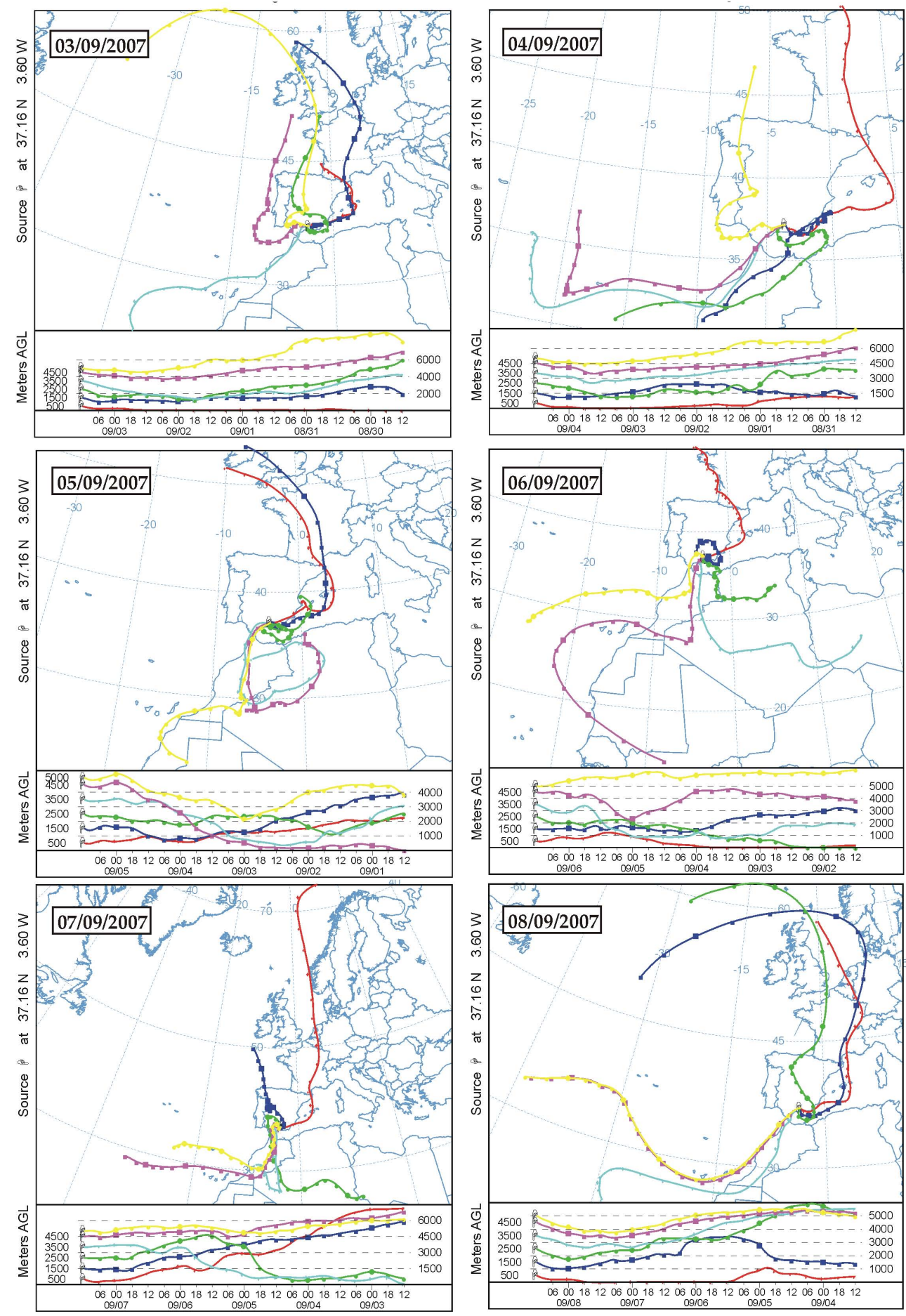

Fig. 1. 5 day back-trajectories ending at Granada at 12:00 GMT at different levels $(500,1500,2500,3500,4500,5000 \mathrm{~m}$ a.g.1.) for the indicated dates.

mode indicates particles with larger size like dust particles. Column-integrated volumetric size distributions, calculated by means of the Cimel CE-318-4 inversions, show the great contribution of the coarse mode in the atmospheric column. On 3 and 4 September the volumetric size distribu- tion presents a balanced bimodal behaviour, indicating a similar relative predominance for fine and coarse particles. Observed differences in the fine mode for the different times reveal changes of the urban contribution (traffic) at our study area. Thus, larger values in fine mode are found early in the 

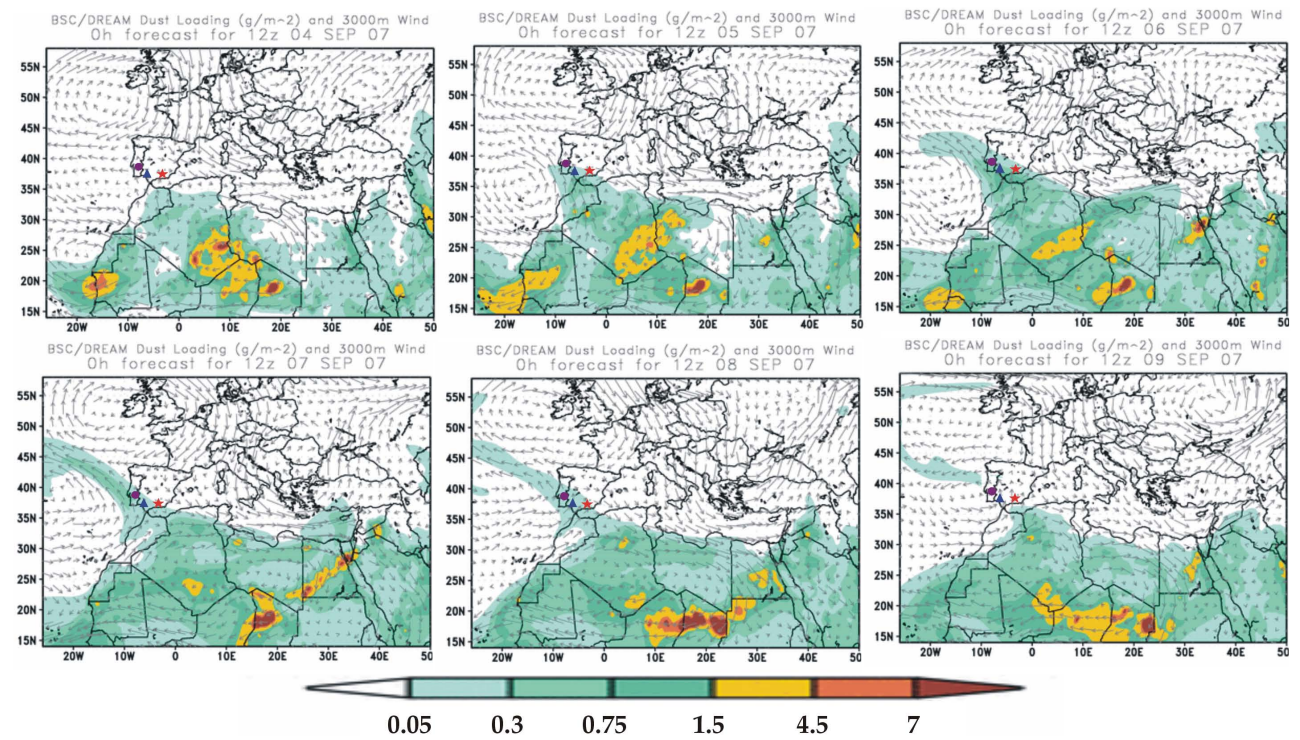

Fig. 2. Dust loading maps $\left(\mathrm{g} / \mathrm{m}^{2}\right)$ and wind vectors at $3000 \mathrm{~m}$ calculated by the DREAM model. This model shows a delay with respect to the NAAPS model (ending day is delayed one day in DREAM with respect to NAAPS). Symbols indicate several stations: Granada (red star), El Arenosillo (blue triangle) and Évora (purple circle).

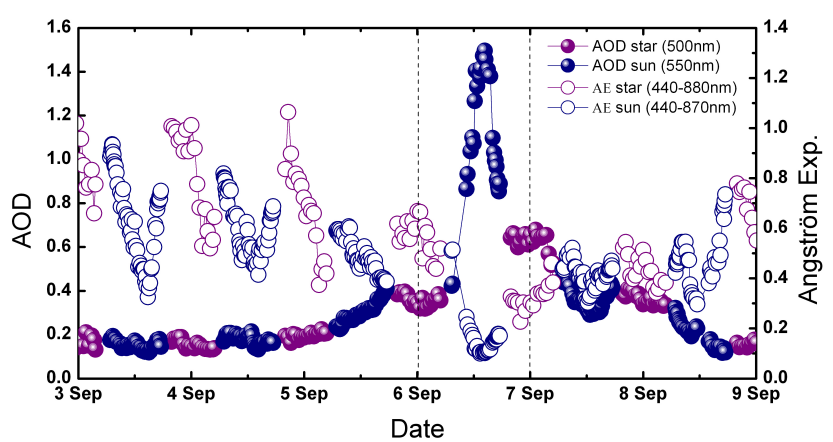

Fig. 3. Aerosol optical depth and Angström exponent obtained by the Cimel CE 318-4 and Excalibur star-photometer. Level 2 data from the Granada station processed by AERONET. Extreme values for both optical properties were identified on 6 September during daytime (between dashed lines), corresponding to the maximum dust loading values, as predicted by the aforementioned models and images.

morning and late in the afternoon. By contrast, the coarse mode is steadier over these days, indicating a quasi permanent background of local mineral dust particles. As a result, a U-shape behaviour is found in the Angström exponent.

Throughout 5 September the coarse mode intensified in agreement with the increasing aerosol optical depth and the decreasing Angström exponent, as observed in the Fig. 3. As a result of this trend, on 6 September extreme volume size distributions are retrieved (note the different scale for this day in Fig. 4). Thus, maximum values in the coarse mode on 6 September are increased by a factor of $\sim 5$ with respect to the maxima detected during other days. The Angström exponent values between 0.12 and 0.17 registered on this day are associated with the largest coarse mode shown in Fig. 4. On 7 September the U-shape behaviour observed in the Angström exponent is explained in terms of first an increase and a later decrease of the coarse mode throughout the day. Finally coarse mode tends to decrease at the end of the event on 8 September.

Contributions to aerosol optical depth by fine and coarse modes have been computed from the Angström exponent values (O'Neill et al., 2001, 2003). The fine mode contribution to the total aerosol optical depth is approximately constant during the event with values below 0.15 except on 6 September when the value increases up to 0.25 , indicating that the aerosol plume can also bring fine particles. This was expected because of the high stability of the fine mode over the analyzed period. In contrast, the coarse mode contribution experiences the same trend as the total aerosol optical depth, indicating that the variability associated in aerosol optical depth is caused by the arrival of coarse particles coming from the Saharan desert. The coarse mode fraction is larger than 0.45 for the whole period and around 0.90 during the most intense day.

Using passive remote sensing tools, this Saharan dust event has been monitored on the basis of Cimel CE-318 sunphotometers included in the AERONET network. (http:// aeronet.gsfc.nasa.gov/). A single ground-based aerosol monitoring station is not enough to assess regional aerosol distributions due to the strong spatial and temporal variability of aerosol particles in the atmosphere, especially during severe dust loading events. AERONET operates three 

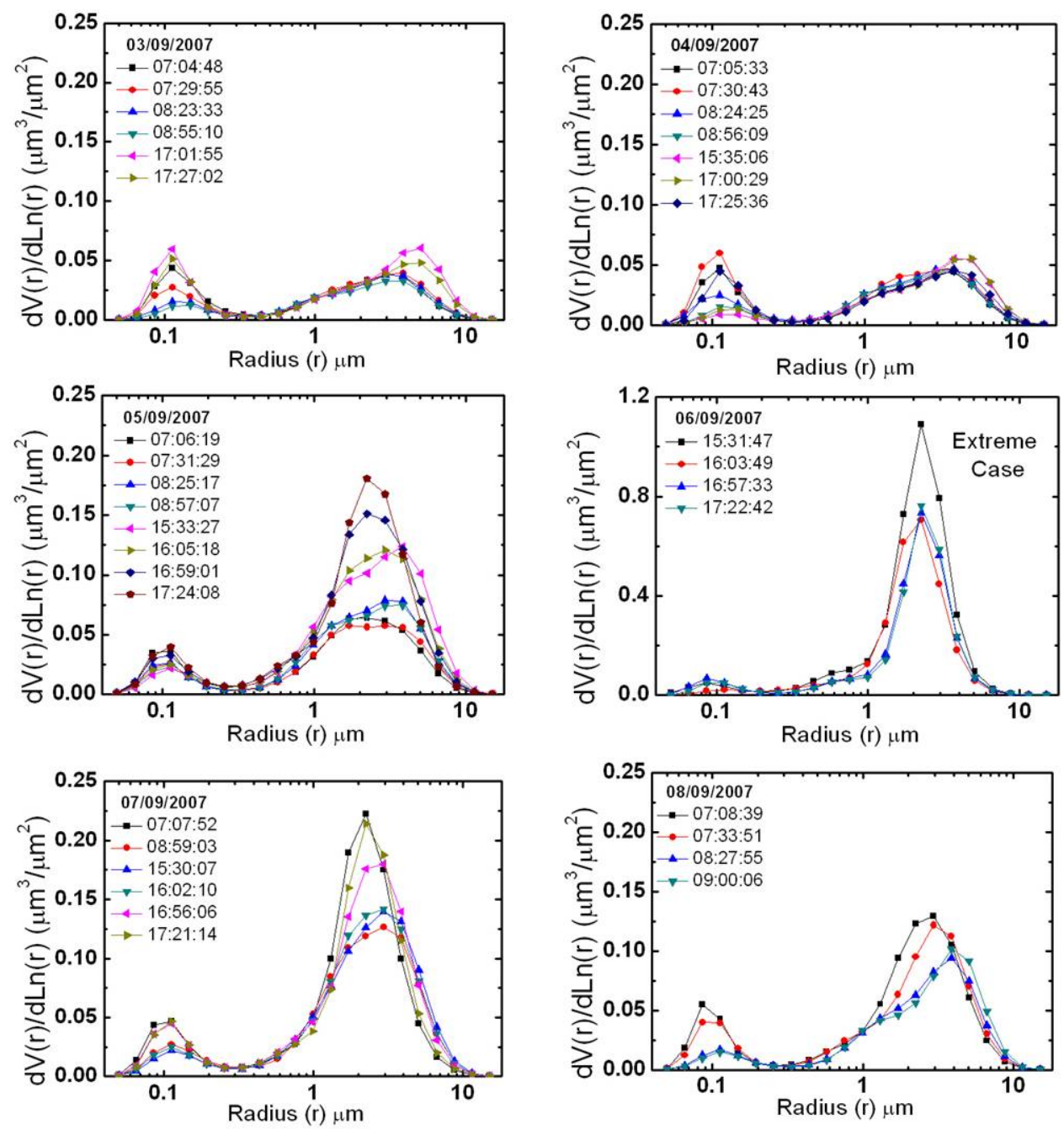

Fig. 4. Size distributions derived from Cimel CE 318-4. Level 2 data (almucantar retrieval, version 2) provided by AERONET. Note the different scale for 6 September. Extreme values for coarse mode values were identified on 6 September, in accordance with the results of the aforementioned models and images. Maximum values on 6 September increased by a factor of $\sim 5$ with respect to the maxima for the other days.

sun-photometers in the southern Iberian Peninsula: Granada (Spain, $37.16^{\circ} \mathrm{N}, 3.61^{\circ} \mathrm{W}, 680 \mathrm{~m}$ a.s.1.), El Arenosillo (Spain, $37.11^{\circ} \mathrm{N}, 6.73^{\circ} \mathrm{W}, 0 \mathrm{~m}$ a.s.1.), and Évora (Portugal, $38.60^{\circ} \mathrm{N}, 7.90^{\circ} \mathrm{W}, 293 \mathrm{~m}$ a.s.1.) (Fig. 2).

The aerosol optical depth at $675 \mathrm{~nm}$ (a wavelength common among the radiometers operated at the different stations), derived from sun-photometers included in AERONET at the three aforementioned stations, is presented in Fig. 5. In order to guarantee the quality of the data, our analyses have been performed on the highest level data provided by AERONET for each station (Level 2 data at Granada and Évora, and Level 1.5 at El Arenosillo). The details of Fig. 5 are worthy of comment. During the study period all stations underwent a Saharan dust outbreak indicated by the increasing aerosol optical depth trends thoughout 5 September. For Granada and El Arenosillo stations the increasing trend achieved the maximum value around 13:30 GMT on 6 September. From this point, the dust load decayed with time down to aerosol optical depths lower than 0.15 , detected over these stations on 8 September. At the El Arenosillo station the detected values were slightly larger than those recorded at Granada during the most intense stage of the Saharan dust event. Nevertheless, the event was delayed by one day over the Évora station as is clear from the high values of aerosol optical depth on 7 September. Furthermore, the highest values detected over Évora during the most intense stage were half those detected at the other stations. This seems to indicate that the dust plume coming from North Africa crossed the southern Iberian Peninsula with the main loads over the Granada and the El Arenosillo stations, and a weaker flank overflew Évora one day later. 


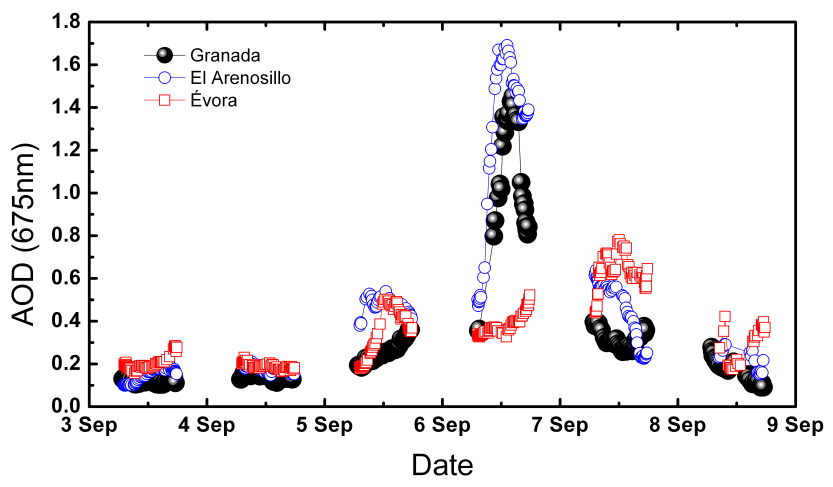

Fig. 5. Aerosol optical depth at $675 \mathrm{~nm}$ derived from Cimel CE 318-4 at three different locations in the southern Iberian Peninsula. Level 2 data provided by AERONET at Granada and Évora, and Level 1.5 at El Arenosillo. Extreme values were identified on 6 September over Granada and El Arenosillo. The event was delayed one day over Évora as is detected by high values of aerosol optical depth on 7 September 2007.

Although the information provided by Fig. 5 is relevant, we must recall that it is restricted to three particular stations that cover the southern Iberian Peninsula. A more complete spatial coverage is given by satellite data. Thus, the global image over the Iberian Peninsula can be analyzed by means of the aerosol optical depth maps generated by the MODIS (v005 collection, spatial resolution $1^{\circ} \times 1^{\circ}$ ), obtained through the Giovanni system from NASA (http: //daac.gsfc.nasa.gov/techlab/Giovanni/). Analyses and visualizations used in this study were produced with the Giovanni online data system, developed and maintained by the NASA Goddard Earth Sciences (GES) Data and Information Services Center (DISC) (Acker and Leptoukh, 2007). The MODIS aerosol optical depth at $550 \mathrm{~nm}$ for the pixels over the considered AERONET stations are shown in Fig. 6, for each day of the period analyzed. On 3 and 4 September aerosol optical depths over the stations are below 0.31 at $550 \mathrm{~nm}$. On 5 September a dust-loaded plume reaches the Iberian Peninsula affecting the South of Spain and Portugal with a maximum aerosol optical depth at $550 \mathrm{~nm}$ of 0.47 . On 6 September an intense broad plume extends from North Africa to the southern Iberian Peninsula with an aerosol optical depth at $550 \mathrm{~nm}$ around 0.6 over Granada and El Arenosillo (half the values observed from surface), and lower than 0.45 over Évora. The event continues its evolution injecting the dust plume into the North Atlantic on 7 September, decreasing its influence over the Spanish stations and increasing it over Évora (aerosol optical depth values around 0.48). Finally, on 8 September the dust plume is almost entirely confined over the North Atlantic, with low values of aerosol optical depth over stations in southern Spain and a remaining contribution over Central Portugal.

This satellite-detected temporal behaviour agrees with that derived from ground-based information, although some dif-

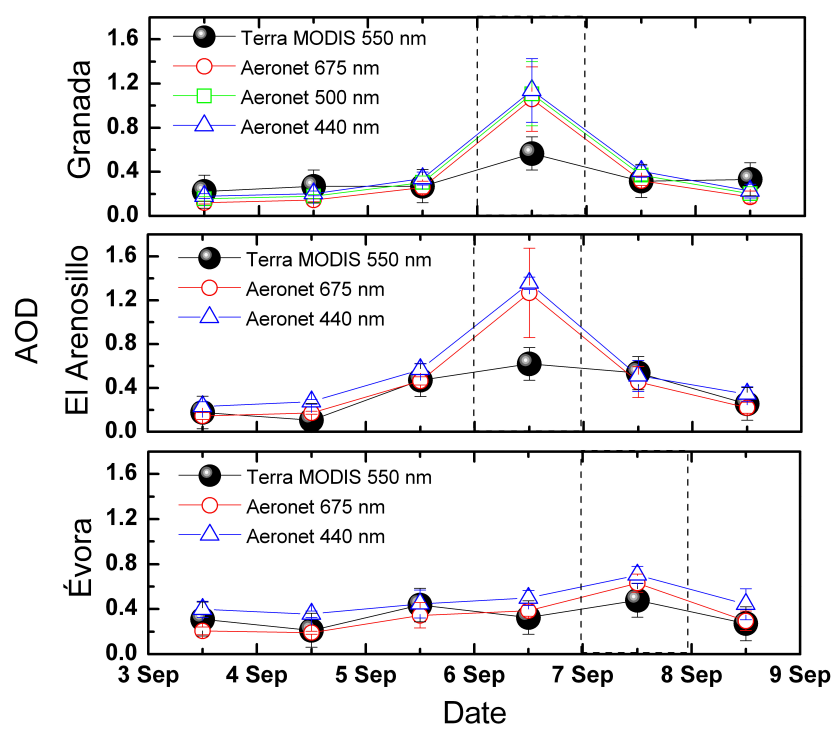

Fig. 6. Daily averaged aerosol optical depth at three AERONET stations obtained by Terra Modis (v005 collection, spatial resolution $\left.1^{\circ} \times 1^{\circ}\right)$ and ground based sun photometers. Dash lines indicate the most intense day during this extreme Saharan dust event.

ferences can be found. Thus, MODIS underestimates aerosol optical depth around 35\% for Granada and Évora stations, and around $60 \%$ for El Arenosillo station. Uncertainties in satellite sensors can be larger under specific areas and circumstances like highly reflecting surfaces, land-ocean subpixel contamination, presence of clouds and non-spherical dust particles (Kaskaoutis et al., 2008). A number of papers have attempted to assess these differences (e.g. Chu et al., 2002; Ichoku et al. 2003; Levy et al., 2005; Remer et al., 2005). Most of these validation studies have shown that although MODIS generally derives aerosol optical depth within the expected error, the instrument tends to overestimate aerosol optical depth in conditions of small loads and underestimate high loads (Chu et al., 2002; Levy et al., 2005; Remer et al., 2005). In our case, the underestimation is marked during the most intense stage of this extreme Saharan dust event.

It is evident that AERONET sun-photometric provides a ground truth for MODIS aerosol products. Satellite derived aerosol optical depth enables a global mapping while ground based stations allow the retrieval of more detailed information about the particle distribution and other aerosol microphysical properties.

\section{Vertical profiles by active remote sensing}

Before focusing on the vertically-resolved quantitative information retrieval, we focus on the time series of Lidar rangecorrected signals. Figure 7 shows several periods from 3 to 7 September (both day and night). This allows us to know what 


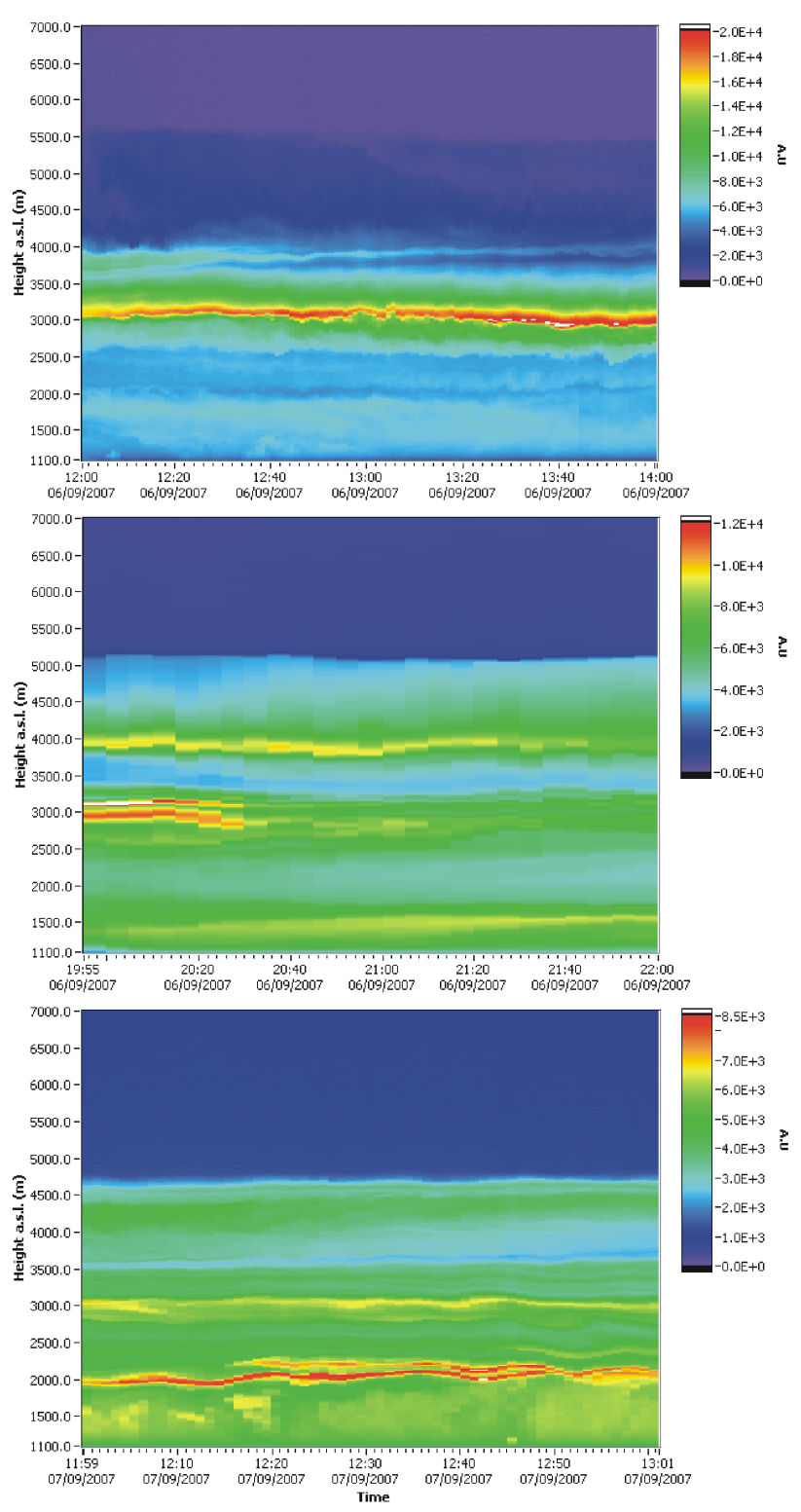

Fig. 7. Temporal evolution of range corrected signal at $532 \mathrm{~nm}$ on 6 and 7 September 2007.

occurs over the station as a function of time. The color scale has been adjusted in the plots in order to enhance the detected layers for each case. Changes can be seen in the vertical distribution of aerosols over the Lidar system throughout the event. As we will see in this section, this event is characterized by a combination of mineral dust particles at higher levels and polluted particles at lower altitudes. On 3 September (not shown here), both day and night, and on 4 September at noon, it is evident that the range-corrected signal inside the planetary boundary layer decreases with altitude. During the night of 4 September an aerosol layer $\sim 3.0 \mathrm{~km}$ (above sea level, a.s.l.) is advected to Granada. During the rest of the event, the vertical range for the aerosol over Granada is higher, exceeding $5.5 \mathrm{~km}$ a.s.l. in some cases, with layers coupled to the planetary boundary layer. It is worth mentioning the layering on 6 and 7 September (Fig. 7). On 6 at noon a layer centered at $3.0 \mathrm{~km}$ a.s.l. is detected with range-corrected signal levels a factor of $\sim 4$ larger than those in lower altitudes. After that, on 6 September at night and 7 September at noon, range-corrected signals in the aerosol plumes do not show such contrast, but the complexity of the vertical structure increases showing a larger number of layers.

Figures 8 and 9 present the aerosol backscatter coefficient and backscatter-related Angström exponent (which describe the spectral dependence of the backscatter coefficient) profiles from 3-7 September at noon. These profiles were computed using the Klett-Fernald-Sasano algorithm (Fernald et al., 1972; Fernald, 1984; Klett, 1981, 1985; Sasano and Nakane, 1984; Sasano et al., 1985) including a synergetic approach with sunphotometer data to select an appropriate Lidar ratio value (Marenco et al., 1997; Landulfo et al., 2003; Guerrero-Rascado et al., 2008). Only profile segments not corrupted by overlap or misalignment effects are considered. Figures 8 and 9 include error bars that consider the effect of the signal noise in the final retrieval. For this purpose Monte Carlo techniques have been used as established in EARLINET network (Pappalardo et al., 2004; GuerreroRascado et al., 2008). The profiles show the aerosol vertical distribution evolution during the Saharan dust event. The combination of these properties allows us to obtain information on the kind of particles present at each altitude.

On 3 and 4 September most of the aerosol load is confined to altitudes below 3.0 and $3.5 \mathrm{~km}$ a.s.l. respectively, and distributed in two different layers. The backscatter-related Angström exponent in the range $355-532 \mathrm{~nm}$ reaches values from slightly below 1 up to 1.2 at the top of the lower layer. This suggests the presence both of fine and coarse particles. This layer is very different from the one located above $2.5 \mathrm{~km}$ a.s.l. where particles are found with a wider range of Angström exponents between 0.9 and 1.6. A similar behaviour is observed for the profiles on 4 September even though the backscatter-related Angström exponent profiles are displaced toward lower values. These findings are in agreement with the air mass origin (Fig. 1) and groundbased photometry observations (Fig. 3) previously mentioned. Thus, the meteorological conditions which favour the stagnation of air masses on 3 September changed slightly on 4 September allowing the arrival of air flows from North Africa. Under this situation some mineral dust can be advected from desert regions. This can be the reason for the decrease in the Angström exponent, detected by sun and star photometry (Fig. 3). However the particle load seems to be not too large, according to the rather low values of aerosol optical depth measured these days (Fig. 3).

The atmospheric vertical structure over Granada changed drastically as is indicated by the optical properties profiles 

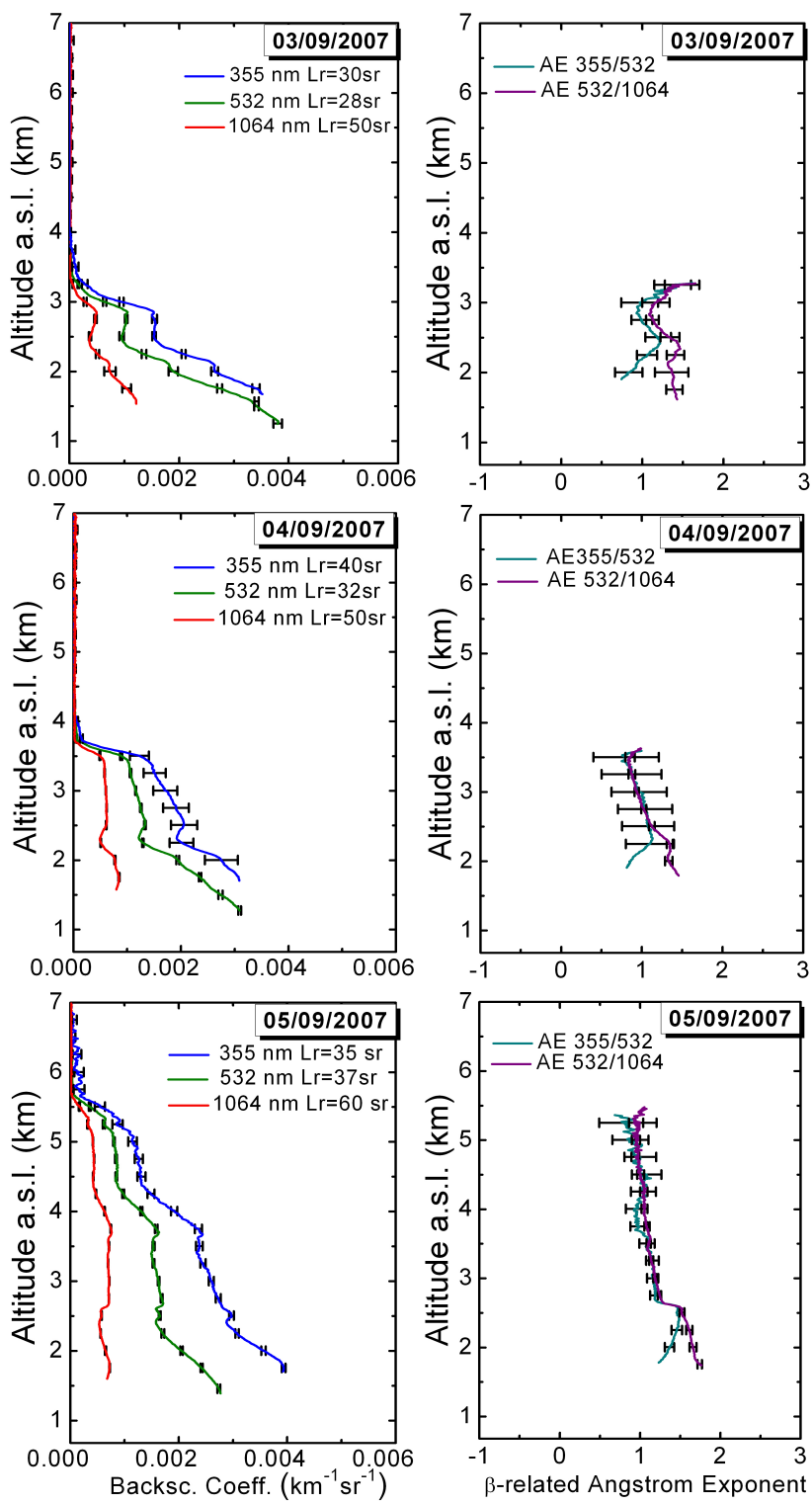

Fig. 8. Vertical profiles of aerosol backscatter coefficient at 355, 532 and $1064 \mathrm{~nm}$, and backscatter-related Angström exponent in the range 355-532 nm and 532-1064 nm for 3-5 September 2007 (profiles averaged 12:00-12:30 GMT). Lidar ratio values used for the Klett-Fernald-Sasano retrieval are included in the graphs. Error bars that consider the effect of signal noise in the final retrieval were retrieved by Monte Carlo techniques.

on 5 September. On this day aerosol particles reached higher altitudes ( $>5.5 . \mathrm{km}$ a.s.1.) showing two differentiated layers. In the upper layer, located between 2.5 and $5.5 \mathrm{~km}$ a.s.l. the Angström exponent was in the range 0.68-1.2. The lowest values were reached at the top of the layer at altitudes where the back-trajectory analyses indicated advection of air masses touching the surface of North Algeria and Morocco. In a lower layer $(<2.5 \mathrm{~km}$ a.s.l.), the Angström exponent
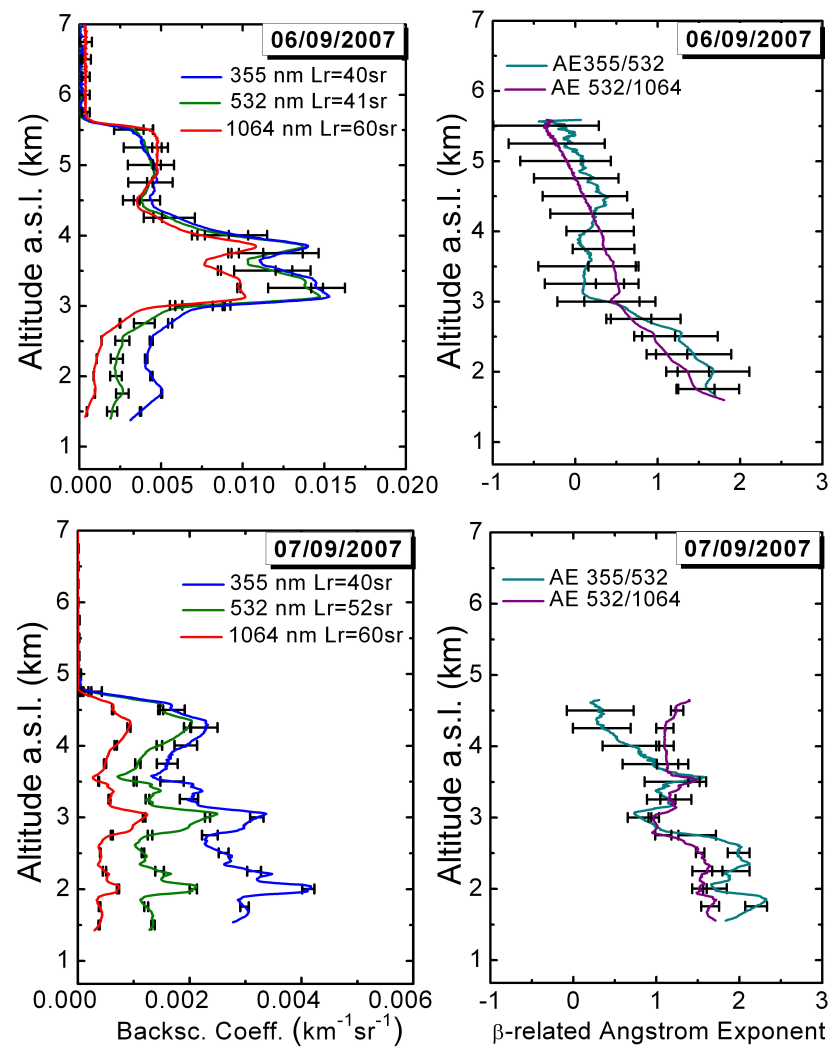

Fig. 9. Vertical profiles of aerosol backscatter coefficient at 355, 532 and $1064 \mathrm{~nm}$, and backscatter-related Angström exponent in the range 355-532 $\mathrm{nm}$ and 532-1064 $\mathrm{nm}$ for 6 and 7 September 2007 (profiles averaged 12:00-12:30 GMT). Lidar ratio values used for the Klett-Fernald-Sasano retrieval are included in the graphs. Error bars that consider the effect of signal noise in the final retrieval were retrieved by Monte Carlo techniques.

ranged from 1.2-1.7. Values observed in this layer are substantially larger than those obtained at higher altitudes as a consequence of advection patterns that incorporate polluted air masses coming from the Mediterranean basin (Fig. 1). Our description of the event, supported by active remote sensing from surface, is coherent with satellite observations. Thus, the attenuated backscatter quicklooks derived from CALIOP on board CALIPSO satellite (Cloud-Aerosol Lidar Infrared Pathfinder Satellite Observations) on 5 September 2007 show aerosol-loaded plumes up to $5.0 \mathrm{~km}$ a.s.l. over areas surrounding Granada (Fig. 10). The observed differences in the vertical distribution of dust particles, detected from surface and satellite, can be justified in terms of the distance between CALIPSO ground-track and Granada (around $78 \mathrm{~km}$ for this CALIPSO overpass). In addition, there is a delay between the CALIPSO overpass $(\sim 13: 30)$ and the Lidar ground based measurements (12:00-12:30 GMT).

During the most intense stage (6 September), the maximum values of aerosol backscatter are eight times greater than for the other days, in temporal coincidence with 


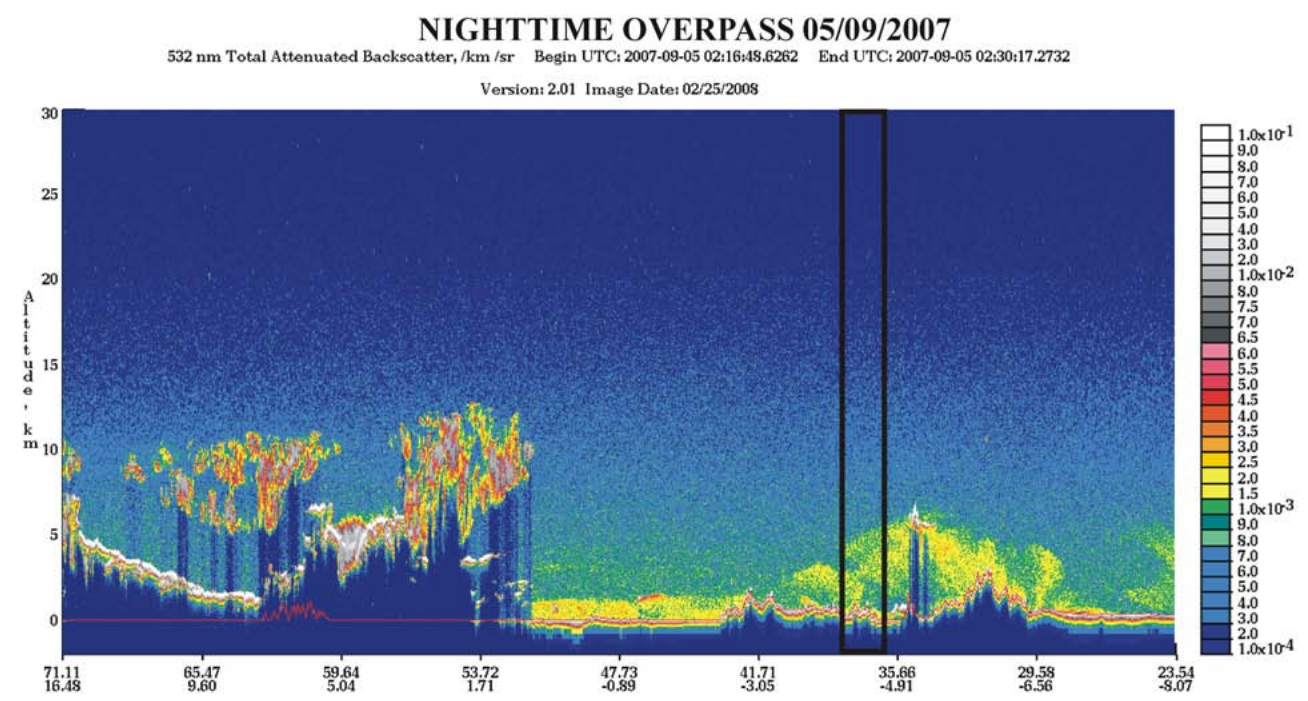

DAYTIME OVERPASS 05/09/2007

$532 \mathrm{~nm}$ Total Attenuated Backscatter, /km /sr Begin UTC: 2007-09-05 13:23:28.9372 End UTC: 2007-09-05 13:36:57.4892

Version: 2.01 Image Date: 02/25/200s

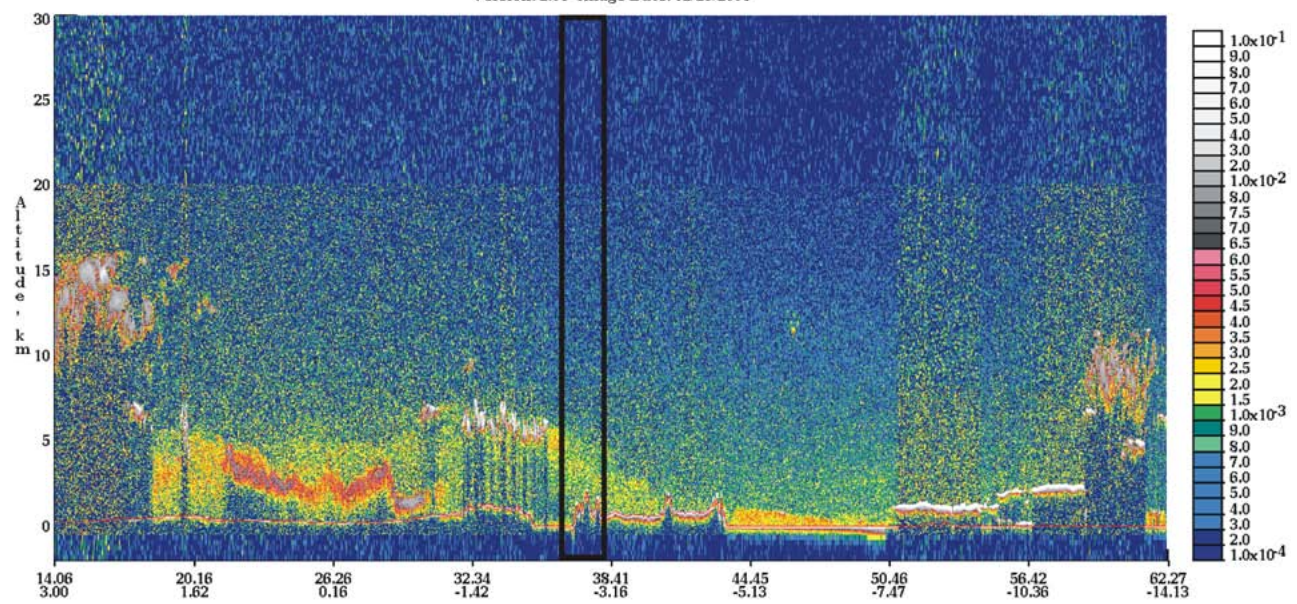

Fig. 10. Attenuated backscatter quicklook derived from CALIOP (CALIPSO satellite) on 5 September 2007 at night (upper panel) and for daytime (lower panel) during the overpasses over EARLINET Granada station. Aerosol-loaded plumes are detected over areas surrounding Granada $\left(37.16^{\circ} \mathrm{N}, 3.61^{\circ} \mathrm{W}\right)$. The black box indicates the area surrounding Granada.

the extreme values for optical properties detected by passive remote sensing (note the different scale for the plot on 6 September in Figs. 8 and 9). Values up to $1.5 \times 10^{-2} \mathrm{~km}^{-1} \mathrm{sr}^{-1}$ at 355 and $532 \mathrm{~nm}$ were detected in the layer with the larger aerosol load between 3.0 and $4.0 \mathrm{~km}$ a.s.l., although aerosol particles were also detected up to $5.5 \mathrm{~km}$ a.s.l. In this stage of the event, dust particles at these altitudes showed a backscatter-related Angström exponent between -0.44 and 0.53 for the two spectral intervals considered, in agreement with the results of other authors (Ansmann et al., 2003; Balis et al., 2004). These results are also in accordance with the aerosol optical depth, Angström exponent and volume size distributions retrieved by sun-photometry. As in previous days, huge differences in optical properties, with respect to those at lower altitudes, were observed. Thus, particles advected at altitudes below $2.5 \mathrm{~km}$ a.s.l. with Mediterranean and local origin showed a backscatter-related Angström exponent up to 1.66, typical of anthropogenic particles (Balis et al., 2004). This kind of data integration from different instruments reveals the importance of performing multi-instrumental measurements to properly characterize the contribution of different aerosol types from different sources during extreme events. As can be seen in Fig. 3, the local and Mediterranean contributions are masked by the spectacular contribution of Saharan dust particles on 6 September from the point of view of sun-photometry.

Finally, the range-corrected signals and optical properties for 7 September (Figs. 7-9) exhibit a complex layering at 

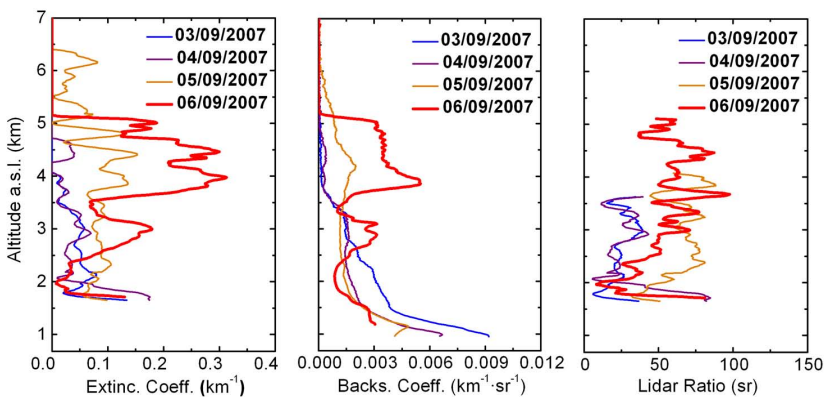

Fig. 11. Vertical profiles of aerosol extinction and backscatter coefficients, and Lidar ratio at $532 \mathrm{~nm}$ computed by Raman algorithm for measurements at night. Lidar data were averaged 20:32-21:02, 20:30-21:00, 20:32-21:02 and 20:30-21:00 GMT for 3, 4, 5 and 6 September 2007, respectively.

the end of the Saharan dust event. An important extension of the profile shows backscatter-related Angström exponents larger than 1. Nevertheless, a backscatter-related Angström exponent around 0.21 detected above $4.0 \mathrm{~km}$ a.s.l. indicates the presence of coarse particles at the highest altitudes.

Figure 11 presents the temporal evolution of extinction, backscatter and Lidar ratio profiles at $532 \mathrm{~nm}$ obtained by Raman algorithm (Ansmann et al., 1992) on 3, 4, 5 and 6 September at night time. These are in agreement with the evolution of backscatter profiles evaluated at noon (Figs. 8 and 9). The different altitudes of the dust layers are related to the temporal evolution of the aerosol properties along the event. The aerosol vertical extension reached up to $4.7 \mathrm{~km}$ a.s.l. during night of 4 September, several hours before the CALIPSO overpass (02:26 GMT). The attenuated backscatter quicklook shown in Fig. 10 indicates an aerosol dustloaded plume up to around $5.0 \mathrm{~km}$ a.s.1. Ground-based profile both elastic and inelastic (Figs. 8, 9 and 11) indicate an aerosol plume up to 4.7 and $5.7 \mathrm{~km}$ a.s.1. on 4 September at night time and 5 September at noon, respectively, in agreement with the CALIPSO retrievals (Fig. 10).

At night the aerosol optical depth derived directly from the Excalibur star-photometer and those computed by integration of the aerosol extinction coefficient profile, derived from Lidar, have been compared. On 5 and 6 September, in coincidence with the largest mineral dust load, the Lidarderived aerosol optical depths at $532 \mathrm{~nm}$ for the period 20:30 to $21: 00$ were 0.44 and 0.63 , respectively. While the corresponding star-photometer values at $500 \mathrm{~nm}$ were 0.38 and 0.66 , respectively. Part of these differences can be explained in terms of the assumption of a height-independent extinction coefficient in the lower atmospheric layers for the Lidar computations. Furthermore, in the case of an atmosphere loaded with mineral dust particles, the requirement of homogeneity could not be fulfilled strictly. Therefore the aerosol optical depth computed along the vertical direction, as in the case of Lidar, and any given slant path, as the one used by the star-photometer, can be different.
The altitude-dependent Lidar ratio can be derived from the independent computation of aerosol extinction and backscatter profiles. The Lidar ratio at $2.0-3.6 \mathrm{~km}$ a.s.1. ranges around $27 \pm 6$ sr and $24 \pm 9$ sr on 3 and 4 September, respectively. On 4 September, below $2.0 \mathrm{~km}$ a.s.l. the Lidar ratio reached values up to $85 \mathrm{sr}$. On 5 September, when dust particles were transported over Granada, the Lidar ratio varied between 50-65 sr in the dust plume. Similar values were derived on 6 September. The Lidar ratios assumed for the elastic algorithm are included in the Figs. 8 and 9. These values, adjusted by comparison with sun-photometric data, are in agreement with the findings of active remote sensing (Raman methodology and backscatter-related Angström exponent profiles at noon) and synoptic analysis (including back-trajectories and modelling results). Thus, on 3 and 4 September the Lidar ratios are below $35 \mathrm{sr}$ at $532 \mathrm{~nm}$, but larger for the rest of the event.

Lidar ratio values found in this study are in agreement with those of other authors. For marine aerosols Müller et al. (2007) found values of $23 \pm 3 \mathrm{sr}$ at $532 \mathrm{~nm}$ in North Atlantic during ACE2, and in the Tropical Indian Ocean during INDOEX (Müller et al., 2007) values of Lidar ratios at $532 \mathrm{~nm}$ of $23 \pm 5$ and $29 \pm 8 \mathrm{sr}$ have been measured in the planetary boundary layer and free troposphere, respectively. Likewise, Lidar ratios at $351 \mathrm{~nm}$ of 23 and $44 \mathrm{sr}$ were registered in southern Italy (De Tomasi and Perrone, 2003). Finally, marine aerosols measured in Greece presented Lidar ratios of $28 \pm 11 \mathrm{sr}$ at $355 \mathrm{~nm}$ (Amiridis et al., 2005). For polluted marine aerosol, values in the range $30-40 \mathrm{sr}$ at $532 \mathrm{~nm}$ were obtained in the Tropical Indic Ocean during INDOEX field campaign (Müller et al., 2007).

On the other hand, mineral dust shows greater variability. In this sense, values in the range 40-80 sr and 50-90 sr at 532 and $355 \mathrm{~nm}$, respectively, were found in Northern Europe (Ansmann et al., 2003). Values of $55 \pm 6 \mathrm{sr}$ at 355 and $532 \mathrm{~nm}$ were registered in the planetary boundary layer for source regions in the Sahara desert during the SAMUM field campaign (Müller et al., 2007) and values of 59 $\pm 11 \mathrm{sr}$ at $532 \mathrm{~nm}$ for particles advected from Sahara desert in the free troposphere over Europe (Müller et al., 2007). Finally, values of $38 \pm 15$ sr at $355 \mathrm{~nm}$ (Mona et al., 2006) and in the range 4874 at 351nm (De Tomasi and Perrone, 2003) were detected in southern Italy, and $51.7 \pm 24.7 \mathrm{sr}$ at $355 \mathrm{~nm}$ in Greece (Balis et al., 2004).

During daytime, the required selection of an effective Lidar ratio can be obtained using the aerosol optical depth derived from the Cimel CE 318-4 as a constraint for the integral of Lidar-derived extinction profiles. Alternatively the Lidar ratio can be obtained directly from Cimel retrievals of single scattering albedo and Phase function by the following expression (Welton et al., 2002):

$L r=\frac{4 \pi}{\omega_{0} P\left(180^{\circ}\right)}$, 
Table 1. Layer contribution (percentage) to the aerosol optical depth at $532 \mathrm{~nm}$, corresponding to the aerosol backscatter profiles shown in Figs. 8, 9 and 11 (D, day; N, night).

\begin{tabular}{llllllll}
\hline \multicolumn{2}{l}{ Date } & \multicolumn{7}{c}{ \% Aerosol optical depth in Layers (a.s.1.) } \\
\hline & $<1.5(\mathrm{~km})$ & $1.5-2.5(\mathrm{~km})$ & $2.5-3.5(\mathrm{~km})$ & $3.5-4.5(\mathrm{~km})$ & $4.5-5.5(\mathrm{~km})$ & $>5.5(\mathrm{~km})$ \\
\hline $03 / 09$ & $\mathrm{D}$ & 51.3 & 34.6 & 11.1 & 1.7 & 0.7 & 0.1 \\
& $\mathrm{~N}$ & 54.4 & 28.2 & 13.7 & 2.2 & 0.7 & 0.4 \\
$04 / 09$ & $\mathrm{D}$ & 43.1 & 32.5 & 20.4 & 2.8 & 0.5 & 0.1 \\
& $\mathrm{~N}$ & 52.4 & 22.6 & 18.2 & 4.5 & 1.4 & 0.5 \\
$05 / 09$ & $\mathrm{D}$ & 27.5 & 25.9 & 19.9 & 15.8 & 9.4 & 0.7 \\
& $\mathrm{~N}$ & 34.7 & 17.9 & 13.8 & 18.6 & 9.8 & 2.5 \\
$06 / 09$ & $\mathrm{D}$ & 6.1 & 9.1 & 33.2 & 33.4 & 16.1 & 1.4 \\
& $\mathrm{~N}$ & 20.7 & 11.0 & 18.4 & 31.4 & 17.5 & 0.3 \\
$07 / 09$ & $\mathrm{D}$ & 18.3 & 24.4 & 26.7 & 24.6 & 5.0 & 0.0 \\
\hline
\end{tabular}

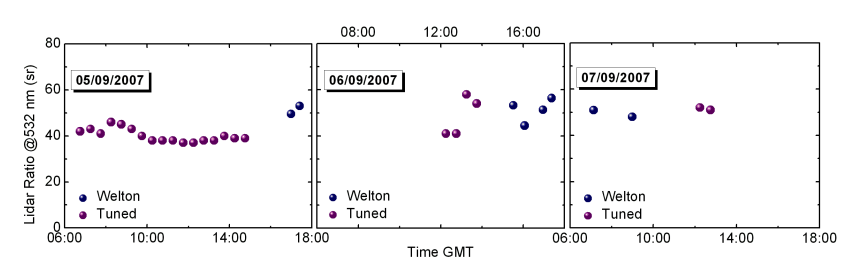

Fig. 12. Lidar ratio at $532 \mathrm{~nm}$ computed by Cimel CE-318 via the Welton formula and computed by integration of tuned aerosol extinction profile (tuning via aerosol optical depth).

where $L r$ is the Lidar ratio, $\omega_{0}$ the single scattering albedo and $P\left(180^{\circ}\right)$ the phase function at $180^{\circ}$. A comparison between these two approaches has been performed (Fig. 12). Time differences are due to the lack of synchronisation between the radiance measurements of Cimel CE 318-4 sunphotometer used to obtain the column-integrated microphysical properties, which fulfil appropriate criteria (symmetry and aerosol optical depth at $440 \mathrm{~nm}>0.4$ ), and the Lidar measurements. In any case, the Lidar ratios derived from the two procedures are in agreement, showing values between 40 and $60 \mathrm{sr}$ for all cases as is typical for Saharan dust events. On 5 September we performed an intense monitoring of the first stage of the Saharan dust event. A pattern can be seen during this day with minimum values at noon and an increasing trend at the end of the day. This behaviour is also seen on the next day (in spite of the low number of data). Finally, the Lidar ratio seems to be stable on 7 September.

According to the previous results on the vertical structure it is evident that the arrival of Saharan dust implied a large increase in the aerosol load in the free troposphere. To estimate the contribution of light extinction by the tropospheric particles to the aerosol optical depth, we calculated the contribution (in percent) to the aerosol optical depth for the different layers. Computations have been performed on the basis of backscatter profiles during daytime and both backscatter and extinction profiles at night. Table 1 presents the contribu- tion of different layers to the aerosol optical depth at $532 \mathrm{~nm}$, computed by considering the vertical profile associated with backscatter profiles at any time. The contribution computed on the basis of extinction profiles differs from that derived from backscatter profiles by less than $6 \%$, except in some cases for the layer below $1.5 \mathrm{~km}$ a.s.l., where the difference is slightly larger. Thus, in the initial stages of the period analyzed the contribution below $2.5 \mathrm{~km}$ a.s.l. reached values around $85 \%$ and $75 \%$ on 3 and 4 September, respectively. During the rest of the event the contribution to the aerosol optical depth does not show large differences up to $4.5 \mathrm{~km}$ a.s.1., except on 6 September at noon where the layer confined between 2.5 and $4.5 \mathrm{~km}$ a.s.1. present a value as large as $67 \%$.

As part of the most recent activities in EARLINET network, a validation of the DREAM model is presented during this extreme Saharan dust event. The vertical profile of the aerosol backscatter coefficient obtained by Lidar is presented in Fig. 13 along with the corresponding mineral dust density profiles forecast by the DREAM model. In order to perform a reliable comparison, forecasts of mineral dust density profiles were chosen in temporal coincidence with Lidar measurements at 12:00 and 21:00 GMT. From this comparison one can see that the DREAM model is able to forecast the main features of dust transport, especially during the day with the most intense values for optical properties (6 September). Thus, on 6 September at noon the DREAM model forecasts correctly the dust layer thickness (about 3 $\mathrm{km}$ ) but underestimates its altitude by around $0.5 \mathrm{~km}$. In addition, the complex layering is not properly predicted. However, at night the DREAM model locates the maximum values of mineral dust density at the altitude at which the Lidar retrieves the maximum values for aerosol backscatter coefficient, around $4.0 \mathrm{~km}$ a.s.l. Again, the Lidar reveals a more complex layering than that forecast by DREAM. Similar behaviour was observed during an extraordinary dust event over Beijing (China) in April 2006 (Papayannis et al., 2007). 

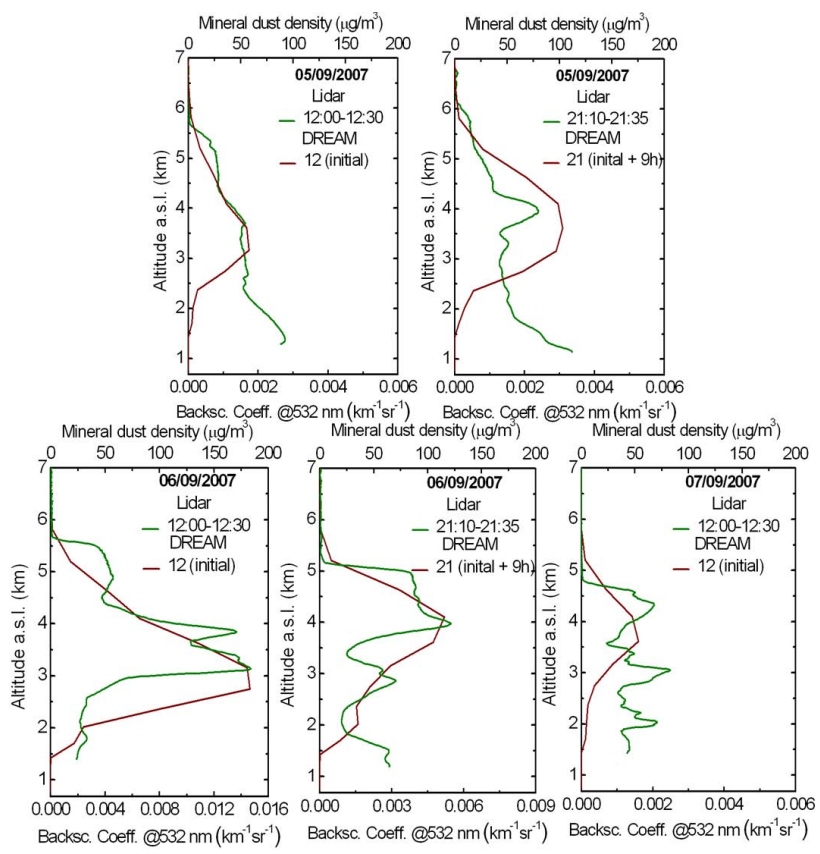

Fig. 13. Aerosol backscatter coefficient profiles, obtained by Lidar at 532, for the most intense days of the analyzed event, both day and night, with the corresponding mineral dust density profiles forecast by the DREAM model.

The differences between the Lidar and the DREAM model are more obvious during the rest of this Saharan dust event, when optical properties achieve values lower than those on 6 September, especially at the lowest altitudes. In any case, the monitoring with aerosol backscatter coefficient and mineral dust density profiles shows good temporal correlation during the most intense dust stage. Therefore, this comparison has permitted validation of the DREAM dust forecast model's vertical profiles over Granada. Possibly, the differences encountered could be minimized using more accurate meteorological data and more realistic regional topography.

\section{Heating rate}

The parameter traditionally used in climate modelling has been the radiative forcing calculated at the top of the atmosphere. Thus, aerosol particles mainly have a net cooling effect, which is a negative radiative forcing, because of the scattering of solar radiation in all directions. Nevertheless, some kind of particles like mineral dust or soot can absorb radiation causing the opposite effect. Therefore, aerosols are able to heat the atmospheric layers in which they are included when they absorb solar radiation, in spite of the possible net cooling effect for the atmospheric column (Pilewskie, 2007). These differing effects for surface and atmosphere have been observed previously. For example, convective coupling between the surface and trophospere is weak during the trop-

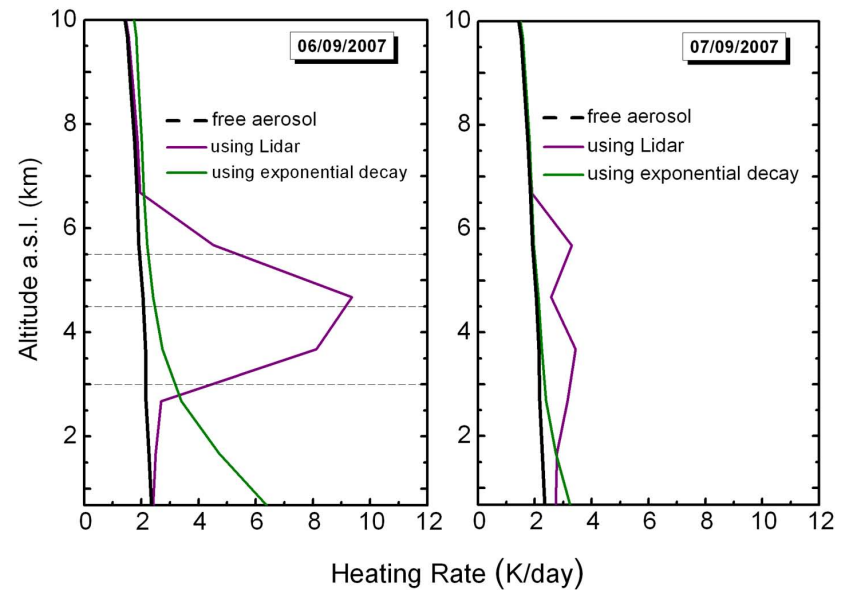

Fig. 14. Vertical distribution of heating rates on 6 and 7 September during the extreme Saharan dust event including the most intense stage. Heating rates were computed using the vertical distribution derived by Lidar (violet), using an exponential decay with aerosol optical depth derived from sun-photometer (green) and using an aerosol free atmosphere (black).

ical dry season, and solar heating by aerosol particles are able to amplify the effect of greenhouse gases warming the atmosphere while simultaneously cooling the surface (Ramanathan et al., 2001). In this sense, our understanding of the vertical heating rate is crucial (Ramanathan et al., 2007).

The absorption of solar radiation caused by several compounds is important for atmospheric heating. This can be quantified by the heating rate (Liou, 2002):

$$
\frac{\partial T(z)}{\partial t}=-\frac{1}{\rho C_{p}} \frac{\Delta F(z)}{\Delta z},
$$

where $\partial T(z) / \partial t$ is the heating rate at altitude $z, \rho$ is the air density, $C_{p}$ is the specific heat at constant pressure, $\Delta F(z)$ is the net flux density divergence for a given layer with thickness $\Delta z$. The SBDART code (http://arm.mrcsb.com/sbdart/) has been used to compute vertical distributions of heating rate during this extreme Saharan dust event. SBDART is a tool that computes plane-parallel radiative transfer both within the atmosphere and at the surface, including all important processes that affect the radiation (Ricchiazzi et al., 1998). This radiative transfer computer code characterizes aerosols using as input the spectral aerosol optical depth, the spectral single scattering albedo, and the spectral asymmetry parameter (derived from radiometric measurements). Other inputs required by the code include the solar zenith angle, total ozone columnar content (retrieved from TOMS, http://toms.gsfc.nasa.gov/), and the selection of an atmospheric model to prescribe the gaseous composition of the atmosphere (summer mid-latitude atmosphere in our case). With respect to the vertical distribution of aerosol three different runs of the code have been considered: (i) aerosolloaded atmosphere using Lidar profile, (ii) aerosol-loaded 
atmosphere using an exponential decay scaled to aerosol optical depth derived by sun-photometer, and (iii) aerosol-free atmosphere.

Figure 14 shows the heating rate profile obtained for two days during this event, including the most intense stage (6 September). For both cases the heating rate has been computed using the real value of the aerosol optical depth. On 6 September the results at surface are completely different depending on the use of a Lidar profile or the assumption of an exponential decay. Thus, for the exponential decay Fig. 14 reveals an overestimation of the heating rate in the range below $3 \mathrm{~km}$ a.s.l. with a maximum of $4 \mathrm{~K} /$ day at surface. However, for upper altitudes $(3 \mathrm{~km}$ to $6.7 \mathrm{~km}$ a.s.l.) the heating rate is underestimated. The maximum value of heating rate is obtained at the upper limit of the most intense layer ( $3 \mathrm{~km}$ to $4.5 \mathrm{~km}$ a.s.l.; Fig. 9). Overestimation around $0.3 \mathrm{~K} /$ day is observed in the free troposphere. Similar overestimation/underestimation trends are observed for the 7 September, but absolute differences are lower than those obtained for the previous day. Therefore, the exponential decay indicates a slight overestimation of the heating rate from the surface up to $1.7 \mathrm{~km}$ a.s.l., with maximum values of $0.4 \mathrm{~K} /$ day, and an underestimation above that altitude up to $6.7 \mathrm{~km}$ a.s.l. Finally, in the free troposphere there is an overestimation with maximum values below $0.1 \mathrm{~K} /$ day.

Large differences in computed heating rates can be observed depending on the vertical distribution of aerosol particles considered. Thus, the lack of knowledge of the real aerosol vertical distribution implies serious discrepancies in the vertical profile of heating rates. For the lower troposphere there is an overestimation, which is especially relevant within the planetary boundary layer, with the largest values near the surface. For altitudes at which lofted aerosol layers are located there is an underestimation, whereas for upper altitudes results are similar with a maximum uncertainty of $0.3 \mathrm{~K} /$ day. The heating rates computed considering the complex structure of atmospheric aerosol profiles suggest strong heating of upper layers that can modify vertical temperature profiles, leading to the formation of a stable layer where vertical exchanges are suppressed. This favours the trapping of aerosol particles below the stable layer and the suppression of cloud development.

\section{$7 \quad$ Summary and conclusions}

Long-range transport of dust from Northern Africa to the southern Iberian Peninsula from 3 to 7 September 2007 was studied based on active and passive remote sensing from surface and satellite to characterize atmospheric aerosol properties and their evolution in time and space (3-D). Analysis of this extreme event (the most intense in south-eastern Iberian Peninsula from August 2004 to December 2008 as registered in AERONET level 2 data) has shown that the synergetic use of active and passive instrumentation including sensors on surface and on board satellite improves our understanding of aerosol properties.

On the basis of photometry, the most intense stage over Granada took place on 6 September at noon, when a combination of large aerosol optical depth, in the range 0.86-1.50 at $500 \mathrm{~nm}$, and reduced Angström exponents, in the range $0.1-0.25$, were detected. The spatial and temporal analyses of this dust mineral plume revealed that several AERONET stations underwent the Saharan dust outbreak, with a temporal evolution that agrees with that described by MODIS. Nevertheless, we found that the aerosol optical depth generated by MODIS underestimates that derived by AERONET (between $35 \%$ and $60 \%$ depending on the station considered), especially during the most intense stage of this extreme Saharan dust event. Such discrepancy has been reported previously by other authors, and can be attributed principally to differences in spatial and temporal scales associated to the satellite and ground-based data.

Lidar measurements have also allowed inference that aerosol particles were distributed in two different layers during the event, although the vertical extent and optical properties were different for each day. During the most intense stage the maximum values of aerosol backscatter $\left(1.5 \times 10^{-2} \mathrm{~km}^{-1} \mathrm{sr}^{-1}\right.$ at 355 and $\left.532 \mathrm{~nm}\right)$ and minimum Angström exponent were monitored (-0.44). These results are in agreement with the aerosol optical depth, Angström exponent and volume size distributions retrieved by sunphotometry. As in previous days, huge differences in optical properties at different altitudes were observed. This suggests the convenience of multi-instrumental measurements to properly characterize the contribution of different aerosol types from different sources during extreme events. Using sun-photometry, local and Mediterranean contributions were masked by the spectacular contribution of Saharan dust particles on 6 September, while Lidar revealed the complex situation. Active remote sensing from surface was coherent with satellite observations. On 5 and 6 September, when dust particles were transported through the atmospheric column over Granada, the Lidar ratio varied between 50-65 sr within the dust plume.

It has been shown that the DREAM model was able to forecast the main features of dust transport, especially during the most intense period. Thus, on 6 September at noon the DREAM model forecast correctly the dust layer thickness but underestimated its altitude slightly, and the complex layering was not properly predicted. The aerosol backscatter coefficient and mineral dust density profiles showed good temporal correlation when the dust event was more intense. The detected discrepancies could likely be minimized using more accurate meteorological data and a more realistic regional topography.

Finally, knowledge of vertical distribution plays an important role in computations of the atmospheric heating rates. Our computations revealed that the lack of knowledge of real aerosol vertical distribution implies an overestimation of 
heating rate in the lower troposphere, especially within the planetary boundary layer, and a marked underestimation in the free troposphere where long-range transport of aerosol particles takes place.

Acknowledgements. This work is supported by the Spanish Ministry of Education project CGL2007-66477-C02-01 and CSD2007-00067, by Andalusian Regional Government projects P06-RNM-01503 and P08-RNM-3568, and by the EARLINETASOS project (EU Coordination Action, contract No. 025991 (RICA)). The authors express gratitude to the NOAA Air Resources Laboratory (ARL), Naval Research Laboratory and Barcelona Supercomputing Center for the HYSPLIT transport and dispersion model, the NAAPs aerosol maps and DREAM model dust data, respectively. We gratefully acknowledge the MODIS mission scientists and associated NASA personnel for the production of the data used in this publication. We also thank AERONET network and specially A. M. Silva and V. E. Cachorro for their efforts in establishing and maintaining the Évora and El Arenosillo AERONET sites. We also acknowledge the NASA's Giovanni, an online data visualization and analysis tool maintained by the Goddard Earth Sciences (GES) Data and Information Services Center (DISC), a part of the NASA Earth-Sun System Division. The authors wish to thank the CALIPSO team at NASA Langley Research Center for providing the data used in our work. We thank A. Kowalski who revised the English translation of the manuscript and also the anonymous referees for their suggestions to improve this work.

Edited by: A. Stohl

\section{References}

Acker, J. G., and Leptoukh, G.: Online analysis enhances use of NASA earth science data, Eos Trans. AGU, 88, 14-17, 2007.

Alados-Arboledas, L., Alcántara, A., Olmo, F. J., Martínez-Lozano, J. A., Estellés, V., Cachorro, V., Silva, A. M., Horvath, H., Gangl, M., Díaz, A., Pujadas, M., Lorente, J., Labajo, A., Sorribas, M., and Pavese, G.: Aerosol columnar properties retrieved from CIMEL radiometers during VELETA 2002, Atmos. Environ., 42, 2654-2667, 2008.

Amiridis, V., Balis, D. S., Kazidzis, S., Bais, A., and Giannakaki, E.: Four-year aerosol observation with a Raman lidar at Thessaloniki, Greece, in the framework of the European Aerosol Research Lidar Network (EARLINET), J. Geophys. Res., 110, D21203, doi:10.1029/2005JD006190, 2005.

Ansmann, A., Wandinger, U., Riebesell, M., Weitkamp, C., and Michaelis, W.: Independent measurement of extinction and backscatter profiles in cirrus clouds by using a combined Raman elastic-backscatter lidar, Appl. Optics, 31, 7113-7131, 1992.

Ansmann A, Bösenberg, J., Chaikovsky, A., Comerón, A., Eckhardt, S., Eixmann, R., Freudenthaler, V., Ginoux, P., Komguem, L., Linné, H., López Márquez, M. A., Matthias, V., Mattis, I., Mitev, V., Müller, D., Music, S., Nickovic, S., Pelon, J., Sauvage, L., Sobolewsky, P., Srivastava, M. K., Stohl, A., Torres, O., Vaughan, G., Wandinger, U., and Wiegner, M.: Long-range transport of Saharan dust to northern Europe: The 11-16 October 2001 outbreak observed with EARLINET, J. Geophys. Res., 108(D24), 4783, doi:10.1029/2003JD003757, 2003.
Balis, D. S., Zerefos, C. S. ,Kourtidis, K., Bais, A. F., Hofzumahaus, A., Kraus, A., Schmitt, R., Blumthaler, M., and Gobbi, G. P.: Measurements and modeling of the photolysis rates during the photochemical activity and ultraviolet radiation (PAUR) II campaign, J. Geophys. Res., 107(D18), 8138, doi:10.1029/2000JD000136, 2002.

Balis, D., Amiridis, V., Nickovic, S., Papayannis, A., and Zerefos, C.: Optical properties of Saharan dust layers as detected by a Raman lidar at Thessaloniki, Greece, Geophys. Res. Lett., 31, L13104, doi:10.1029/2004GL019881, 2004.

Bösenberg, J., Ansmann, A., Baldasano, J. M., Balis, D., Böckmann, C., Calpini, B., Chaikovsky, A., Flamant, P., Hagard, A., Mitev, V., Papayannis, A., Pelon, J., Resendes, D., Schneider, J., Spinelli, N., Trickl, T., Vaughan, G., Visconti, G., and Wiegner, M.: EARLINET: a European aerosol research lidar network, laser remote sensing of the atmosphere, in: Selected Papers of the 20th International Laser Radar Conference, 2001, edited by: Dabas, A., Loth, C., and Pelon, J., Edition Ecole Polytechnique, Palaiseau, France, 155-158, 2001.

Cachorro, V. E., Toledano, C., Prats, N., Sorribas, M., Mogo, S., Berjón, A., Torres, B., Rodrigo, R., de la Rosa, J., and De Frutos, A. M.: The strongest desert dust intrusion mixed with smoke over the Iberian Peninsula registered with sun photometry, J. Geophys. Res., 113, D14S04, doi:10.1029/2007JD009582, 2008.

Chu, D. A., Kaufman, Y. J., Ichoku, C., Remer, L. A., Tanré, D., and Holben, B.: Validation of MODIS aerosol optical depth retrieval over land, Geophys. Res. Lett., 29(12), 8007, doi:10.1029/2001GL013205, 2002.

De Tomasi, F., Blanco, A., and Perrone, M. R.: Raman lidar monitoring of extinction and backscattering of African dust layers and dust characterization, Appl. Optics, 42, 1699-1709, 2003.

De Tomasi, F. and Perrone, M. R.: Lidar measurements of tropospheric water vapor and aerosol profiles over southeastern Italy, J. Geophys. Res., 108(D9), 4286, doi:10.1029/2002JD002781, 2003.

Díaz, A. M., García, O. E., Díaz, J. P., Expósito, F. J., Utrillas, M. P., Martínez-Lozano, J. A., Alados-Arboledas, L., Olmo, F. J., Lorente, J., Cachorro, V., Horvath, H., Labajo, A., Sorribas, M., Vilaplana, J. M., Silva, A. M., Elias, T., Pujadas, M., Rodrigues, J. A., and González, J. A.: Aerosol radiative forcing efficiency in the UV region over southeastern Mediterranean: VELETA2002 campaign, J. Geophys. Res., 112, D06213, doi:10.1029/2006JD007348, 2007.

Draxler, R. R. and Rolph, G. D.: HYSPLIT (HYbrid single- particle Lagrangian integrated trajectory) Model access via NOAA ARL READY Website (http://www.arl.noaa.gov/ready/hysplit4.html), NOAA Air Resources Lab., Silver Spring, MD, USA, 2003.

Elias, T., Silva, A. M., Belo, N., Pereira, S., Formenti, P., Helas, G., and Wagner, F.: Aerosol extinction in a remote continental region of the Iberian Peninsula during summer, J. Geophys. Res., 111, D14204, doi:10.1029/2005JD006610, 2006.

Fernald, F. G., Herman, B. M., and Reagan, J. A.: Determination of aerosol height distribution by lidar, J. Appl. Meteorol., 11, 482489, 1972.

Fernald, F. G.: Analysis of atmospheric lidar observations: some comments, Appl. Optics, 23, 652-653, 1984.

Forster, P., Ramaswamy, V., Artaxo, P., Berntsen, T., Betts, R., Fahey, D. W., Haywood, J., Lean, J., Lowe, D. C., Myhre, G., 
Nganga, J., Prinn, R., Raga, G., Schulz, M., and Van Dorland, R.: Changes in atmospheric constituents and in radiative forcing, in: Climate Change 2007: The Physical Science Basis. Contribution of Working Group I to the Fourth Assessment Report of the Intergovernmental Panel on Climate Change, edited by: Solomon, S., Qin, D., Manning, M., Chen, Z., Marquis, M., Averyt, K. B., Tignor, M., and Miller, H. L., Cambridge University Press, Cambridge, UK and New York, NY, USA, 2007.

Gobbi, G. P., Barnaba, F., Giorgi, R., and Santacasa, A.: Altituderesolved properties of a Saharan dust event over the Mediterranean, Atmos. Environ., 34, 5119-5127, 2000.

Guerrero-Rascado, J. L., Ruiz, B., Alados-Arboledas, L.: Multispectral lidar characterization of the vertical structure of Saharan dust aerosol over southern Spain, Atmos. Environ., 42, 26682681, 2008.

Hamonou, E., Chazette, P., Balis, D., Dulac, F., Scheider, X., Galani, E., Ancellet, G., and Papayannis, A.: Characterization of the vertical structure of Saharan dust export to the Mediterranean basin, J. Geophys. Res., 104, 22270-22275, 1999.

Holben, B. N., Eck, T. F., Slutsker, I., Tanre, D., Buis, J. P., Setzer, A., Vermote, E., Reagan, J. A., Kaufman, Y. J., Nakajima, T., Lavenu, F., Jankowiak, I., and Smirnov, A.: Aeronet - a federated instrument network and data archieve for aerosol characterization, Rem. Sens. Environ., 66, 1-19, 1998.

Ichoku, C., Remer, L. A., Kaufman, Y. J. Levy, R., Chu, D. A. , Tanré, D., and Holben, B. N.: MODIS observation of aerosols and estimation of aerosol radiative forcing over southern Africa during SAFARI 2000, J. Geophys. Res, 108(D13), 8499, doi:10.1029/2002JD002366, 2003.

Kaskaoutis, D. G., Kambezidis, H. D., Nastos, P. T., and Kosmopoulos, P. G.: Study on an intense dust storm over Greece, Atmos. Environ., 42, 6884-6896, 2008.

Klett, J. D.: Stable analytic inversion solution for processing lidar returns, Appl. Optics, 20, 211-220, 1981.

Klett, J. D.: Lidar inversion with variable backscatter/extinction ratios, Appl. Optics, 24, 1638-1643, 1985.

Kremling, K. and Streau, P.: Saharan dust influenced trace element fluxes in deep North Atlantic subtropical waters, Deep-Sea Res., Pt. I, 40, 1155-1168, 1993.

Landulfo, E., Papayannis, A., Artaxo, P., Castanho, A. D. A., de Freitas, A. Z., Ouza, R. F., Vieira Junior, N. D., Jorge, M. P. M. P., Sánchez-Ccoyllo, O. R., and Moreira, D. S.: Synergetic measurements of aerosols over Sao Paulo, Brazil using LIDAR, sunphotometer and satellite data during the dry season, Atmos. Chem. Phys., 3, 1523-1539, 2003, http://www.atmos-chem-phys.net/3/1523/2003/.

Levy, R. C., Remer, L. A., Martins, J. V., Kaufman, Y. J., PlanaFattori, A., Redemann, J., and Wenny, B.: Evaluation of the MODIS aerosol retrievals over ocean and land during CLAMS, J. Atmos. Sci., 62(4), 974-992, 2005.

Liou, K. N.: An Introduction to Atmospheric Radiation, 2nd edn., International Geophysics Series, Academic Press, Amsterdam, The Netherlands, 84, 107-110, ISBN: 0-12-451451-0, 2002.

Liu, Z., Omar, A., Vaughan, M., Hair, J., Kittaka, C., Hu, Y., Powell, K., Trepte, C., Winker, D., Hostetler, C., Ferrare, R., and Pierce, R.: CALIPSO lidar observations of the optical properties of Saharan dust: A case study of long-range transport, J. Geophys. Res., 113, D07207, doi:10.1029/2007JD008878, 2008.

López, J. M., Callén, M. S., Murillo, R., García, T., Navarro, M. V., de la Cruz, M. T., and Mastral, A. M.: Levels of selected metals in ambient air $\mathrm{PM}_{10}$ in an urban site of Zaragoza (Spain), Env. Res., 99, 58-67, 2005.

Lyamani, H., Olmo, F. J., and Alados-Arboledas, L.: Long-term changes in aerosol radiative properties at Armilla (Spain), Atmos. Environ., 38, 5935-5943, 2004.

Lyamani, H., Olmo, F. J., and Alados-Arboledas, L.: Saharan dust outbreak over southeastern Spain as detected by sun photometer, Atmos. Environ., 39, 7276-7284, 2005.

Lyamani, H., Olmo, F. J., Alcántara, A., and Alados-Arboledas, L.: Atmospheric aerosols during the 2003 heat wave in southeastern Spain I: Spectral optical depth, Atmos. Environ., 40, 6453-6464, 2006a.

Lyamani, H., Olmo, F. J., Alcántara, A., and Alados-Arboledas, L.: Atmospheric aerosols during the 2003 heat wave in southeastern Spain II: Microphysical columnar properties and radiative forcing, Atmos. Environ., 40, 6465-6476, $2006 \mathrm{~b}$.

Lyamani, H., Olmo, F. J., and Alados-Arboledas, L.: Light scattering and absorption properties of aerosol particles in the urban environment of Granada, Spain, Atmos. Environ., 42, 2630-2642, 2008.

Marenco, F., Santacesaria, V., Bais, A., Balis, D., di Sarra, D., Papayannis, A., and Zerefos, C. S.: Optical properties of tropospheric aerosols determined by lidar and spectrophotometric measurements (PAUR campaign), Appl. Optics, 36, 6785-6886, 1997.

Mona, L., Amodeo, A., Pandolfi, M., and Pappalardo, G.: Saharan dust intrusions in the Mediterranean area: Three years of Raman lidar measurements, J. Geophys. Res., 111, D16203, doi:10.1029/2005JD006569, 2006.

Müller, D., Ansmann, A., Mattis, I., Tesche, M., Wandinger, U., Althausen, D., and Pisani, G.: Aerosol-type-dependent lidar ratios observed with Raman lidar, J. Geophys. Res., 112, D16202, doi:10.1029/2006JD008292, 2007.

Müller, D., Heinold, B., Tesche, M., Tegen, I., Althausen, D., Amiridis, V., Amodeo, A., Ansmann, A., Alados-Arboledas, L., Balis, D., Comerón, A., D’Amico, G., Gerasopoulos, E., Guerrero-Rascado, J. L., Freudenthaler, V., Giannakaki, E., Heese, B., Iarlori, M., Mamouri, R. E., Mona, L., Papayannis, A., Pappalardo, G., Perrone, M. R., Pisani, G., Rizi, V., Sicard, M., Spinelli, N., and Tafuro, A.: EARLINET Observations of the 14-22-May long-range dust transport event during SAMUM 2006: Validation of results from dust transport modelling, Tellus, 61B, 325-339, 2009.

Olmo, F. J., Lyamani, H., Tovar, J., and Alados-Arboledas, L.: Volcanic aerosol effects on radiometric series registered at Spain, J. Aer. Sci., 30, S891-S892, 1999.

O’Neill, N. T., Dubovik, O., and Eck, T. F.: Modified Ångström exponent for the characterization of submicrometer aerosols, Appl. Optics, 40, 2368-2375, 2001.

O’Neill, N. T., Eck, T. F., Smirnov, A., Holben, B. N., and Thulasiraman, S.: Spectral discrimination of coarse and fine mode optical depth, J. Geophys. Res., 108(D17), 4559, doi:10.1029/2002JD002975, 2003.

Pappalardo, G., Amodeo, A., Amoruso, S., Mona, L., Pandolfi, M., and Cuomo, V.: One year of tropospheric lidar measurements of aerosol extinction and backscatter, Ann. Geophysics, 46, 401413, 2003.

Papayannis, A., Balis, D., Amiridis, V., Chourdakis, G., Tsaknakis, 
G., Zerefos, C., Castanho, A. D. A., Nickovic, S., Kazadzis, S., and Grabowski, J.: Measurements of Saharan dust aerosols over the Eastern Mediterranean using elastic-Raman lidar, spectrophotometric and satellite observations in the frame of the EARLINET project, Atmos. Chem. Phys., 5, 2065-2079, 2005, http://www.atmos-chem-phys.net/5/2065/2005/.

Papayannis, A., Zhang, H. Q., Amiridis, V., Ju, H. B., Chourdakis, G., Georgoussis, G., Pérez, C., Chen, H. B., Goloub, P., Mamouri, R. E., Kazadzis, S., Paronis, D., Tsaknakis, G., and Baldasano, J. M.: Extraordinary dust event over Beijing, China, during April 2006: Lidar, Sun photometric, satellite observations and model validation, J. Geophys. Res., 34, L07806, doi:10.1029/2006GL029125, 2007.

Papayannis, A., Amiridis, V., Mona, L., Tsaknakis, G., Balis, D., Bösenberg, J., Chaikovski, A., De Tomasi, F., Grigorov, I., Mattis, I., Mitev, V., Müller, D., Nickovic, S., Pérez, C., Pietruczuk, A., Pisani, G., Ravetta, F., Rizi, V., Sicard, M., Trickl, T., Wiegner, M., Gerding, M., Mamouri, R. E., D'Amico, and G. Pappalardo, G.: Systematic lidar observations of Saharan dust over Europe in the frame of EARLINET (2000-2002), J. Geophys. Res., 113, D10204, doi:10.1029/2007JD009028, 2008.

Pappalardo, G., Amodeo, A., Pandolfi, M., Wandinger, U., Ansmann, A., Bösenberg, J., Matthias, V., Amiridis, V., De Tomasi, F., Frioud, M., Iarlori, M., Komguem, L., Papayannis, A., Rocadenbosch, F., and Wang, X.: Aerosol lidar intercomparison in the framework of EARLINET project. 3. Raman lidar algorithm for aerosol extinction, backscatter, and lidar ratio, Appl. Optics, 43, 5370-5385, 2004.

Pérez, C., Nickovic, S., Sicard, M., Rocadenbosh, F., and Cachorro, V. E.: A long Saharan dust event over the western Mediterranean: Lidar, Sun photometer observations, and regional dust modelling, J. Geophys. Res., 111, D15214, doi:10.1029/2005JD006579, 2006.

Pérez-Ramírez, D., Aceituno, J., Ruiz, B., Olmo, F. J., and AladosArboledas, L.: Development and calibration of a star photometer to measure the aerosol optical depth: Smoke observations at a high mountain site, Atmos. Environ., 42, 2733-2738, 2008a.

Pérez-Ramírez, D., Ruiz, B., Aceituno, J., Olmo, F. J., and AladosArboledas, L.: Application of Sun/star photometry to derive the aerosol optical depth, I. J. Remote Sens., 29, 5113-5132, 2008 b.

Pilewskie, P.: Aerosols heat up, Nature, 448, 541-542, 2007.

Ramanathan, V., Ramana, M. V., Roberts, G., Kim, D., Corrigan, C., Chung, C., and Winker, D.: Warming trends in Asia amplified by brown cloud solar absorption, Nature, 448, 575-578, 2007.
Ramanathan, V., Crutzen, P. J., Lelieveld, J., Mitra, A. P., Althausen, D., Anderson, J., Andreae, M. O., Cantrell, W., Cass, G. R., Chung, C. E., Clarke, A. D., Coakley, J. A., Collins, W. D., Conant, W. C., Dulac, F., Heintzenberg, J., Heymsfield, A. J., Holben, B., Howell, S., Hudson, J., Jayaraman, A., Kiehl, J. T., Krishnamurti, T. N., Lubin, D., McFarquhar, G., Novakov, T., Ogren, J. A., Podgorny, I. A., Prather, K., Priestley, K., Prospero, J. M., Quinn, P. K., Rajeev, K., Rasch, P., Rupert, S., Sadourny, R., Satheesh, S. K., Shaw, G. E., Sheridan, P., and Valero, F. P. J.: Indian ocean experiment: an integrated analysis of the climate forcing and effects of the great Indo-Asian haze, J. Geophys. Res., 106(D22), 28371-28398, doi:10.1029/2001JD900133, 2001.

Reichholf, J. H.: Is Saharan dust a major source of nutrients for the Amazonian forest, Suud. Neotrop. Fauna Environ., 21, 251-255, 1986.

Remer, L. A., Kaufman, Y. J., Tanré, D., Mattoo, S., Chu, D. A., Martins, J. V., Li, R. R., Ichoku, C., Levy, R. C., Kleidman, R. G., Eck, T. F., Vermote, E., and Holben, B. N.: The MODIS aerosol algorithm, products, and validation, J. Atmos. Sci., 62(4), 947973, 2005.

Ricchiazzi, P., Yang, S. R., Gautier, C., and Sowle, D.: SBDART: a research and teaching software tool for plane parallell radiative transfer in the Earth's atmosphere, B. Am. Meteor. Soc., 79(10), 2101-2114, 1998.

Sasano, Y. and Nakane, H.: Significance of the extinction/backscatter ratio and the boundary value term in the solution for the two-component lidar equation, Appl. Optics, 23, 11-13, 1984.

Sasano, Y., Browell, E. V., and Ismail, S.: Error caused by using a constant extinction/backscattering Ratio in Lidar solution, Appl. Optics, 24, 3929-3932, 1985.

Welton, E. J., Voss, K. J., Quinn, P. K., Flatau, P. J., Markowicz, K., Campbell, J. R., Spinhirne, J. D., Gordon, H. R., and Johnson, J. E.: Measurements of aerosol vertical profiles and optical properties during INDOEX 1999 using micropulse lidars, J. Geophys. Res., 107(D19), 8019, 18-1-18-20, 2002.

Zerefos, C. S., Kourtidis, K. A., Melas, D., Balis, D., Zanis, P., Katsaros, L., Mantis, H. T., Repapis, C., Isaksen, I., Sundet, J., Herman, J., Bhartia, P. K., and Calpini, B.: Photochemical activity and solar ultraviolet radiation modulation factors (PAUR): An overview of the project, J. Geophys. Res., 107(D18), 8134, doi:10.1029/2000JD000134, 2002. 